\title{
Recombinant $O$-mannosylated protein production (PstS-1) from Mycobacterium tuberculosis in Pichia pastoris (Komagataella phaffii) as a tool to study tuberculosis infection
}

\author{
Giroshi Bando-Campos ${ }^{1 \dagger}$, Daniel Juárez-López ${ }^{1 \dagger}$, Sergio A. Román-González², Antonia I. Castillo-Rodal², \\ Clarita Olvera ${ }^{4}$, Yolanda López-Vidal ${ }^{3}$, Roberto Arreguín-Espinosa ${ }^{5}$, Clara Espitia ${ }^{6}$, Mauricio A. Trujillo-Roldán ${ }^{7}$ \\ and Norma A. Valdez-Cruz ${ }^{1 *}$ (1)
}

\begin{abstract}
Background: Pichia pastoris (syn. Komagataella phaffi) is one of the most highly utilized eukaryotic expression systems for the production of heterologous glycoproteins, being able to perform both $\mathrm{N}$ - and $\mathrm{O}$-mannosylation. In this study, we present the expression in P. pastoris of an O-mannosylated recombinant version of the $38 \mathrm{kDa}$ glycolipoprotein PstS-1 from Mycobacterium tuberculosis (Mtb), that is similar in primary structure to the native secreted protein.

Results: The recombinant PstS-1 (rPstS-1) was produced without the native lipidation signal. Glycoprotein expression was under the control of the methanol-inducible promoter PAOX1, with secretion being directed by the a-mating factor secretion signal. Production of rPstS-1 was carried out in baffled shake flasks (BSFs) and controlled bioreactors. A production up to $46 \mathrm{mg} / \mathrm{L}$ of the recombinant protein was achieved in both the BSFs and the bioreactors. The recombinant protein was recovered from the supernatant and purified in three steps, achieving a preparation with 98\% electrophoretic purity. The primary and secondary structures of the recombinant protein were characterized, as well as its O-mannosylation pattern. Furthermore, a cross-reactivity analysis using serum antibodies from patients with active tuberculosis demonstrated recognition of the recombinant glycoprotein, indirectly indicating the similarity between the recombinant PstS-1 and the native protein from Mtb.
\end{abstract}

Conclusions: rPstS-1 (98.9\% sequence identity, O-mannosylated, and without tags) was produced and secreted by P. pastoris, demonstrating that this yeast is a useful cell factory that could also be used to produce other glycosylated Mtb antigens. The rPstS-1 could be used as a tool for studying the role of this molecule during Mtb infection, and to develop and improve vaccines or kits based on the recombinant protein for serodiagnosis.

Keywords: Mycobacterium tuberculosis, Antigen, Glycoprotein, Pichia pastoris, PstS-1, O-mannosylation, Komagataella phaffii

\footnotetext{
*Correspondence: adri@biomedicas.unam.mx

${ }^{\dagger}$ Giroshi Bando-Campos and Daniel Juárez-López contributed equally to

this work

${ }^{1}$ Programa de Investigación de Producción de Biomoléculas,

Departamento de Biología Molecular y Biotecnología, Instituto de

Investigaciones Biomédicas, Universidad Nacional Autónoma de México,

AP. 70228, CP. 04510 Ciudad de México, Mexico

Full list of author information is available at the end of the article
}

(c) The Author(s) 2019. This article is distributed under the terms of the Creative Commons Attribution 4.0 International License (http://creativecommons.org/licenses/by/4.0/), which permits unrestricted use, distribution, and reproduction in any medium, provided you give appropriate credit to the original author(s) and the source, provide a link to the Creative Commons license, and indicate if changes were made. The Creative Commons Public Domain Dedication waiver (http://creativecommons.org/ publicdomain/zero/1.0/) applies to the data made available in this article, unless otherwise stated. 


\section{Background}

Pulmonary tuberculosis (TB) is caused by the bacterium Mycobacterium tuberculosis (Mtb) and is the second most prevalent infectious disease in the world. In 2016, the World Health Organization reported 10.4 million new TB infections, and 1.3 million deaths due to disease complications, in addition to the fact that about a quarter of the world population is suspected to be infected with the mycobacterium in a clinically latent form [1]. In the same year, it was estimated that approximately 600,000 people developed multidrug-resistance (MDR) to TB [1]. These data reflect the urgency in understanding the pathogenicity of $M t b$, as well as the necessity to develop new therapeutic alternatives to treat or prevent the disease. The interaction of this bacillus with the host has been extensively studied for a long time, with the research effort focusing on its virulence factors, such as antigens [2-8]. The production of recombinant $M t b$ antigens is important in several aspects of Mtb research, for example, in studying antigen interactions and their effect in vivo and in vitro [9-13], in the designing effective vaccines against $M t b[14,15]$, as well as in developing diagnostic tools for $\mathrm{TB}[2,3,8,16,17]$. In fact, the use of recombinant antigens to detect both latent and active TB provides for a simpler and more accurate diagnosis compared to other diagnostic tests in use today, such as the purified protein derivative (PPD) skin test or the QuantiFERON ${ }^{\circledR}$-TB test [18-21]. For these reasons, it is important to be able to produce antigens with conformations that are as similar as possible to the native antigens produced by the mycobacteria so they can used as reagents in the development of diagnostic tools or vaccines.

$M t b$ produces a variety of secreted protein antigens and these can be found in culture supernatants. Some of these, such as Rv2164c, Rv3491, Rv0175, Rv1887, Rv1096, Rv2068c, Rv2744c, Rv2799, Rv3835, and Rv1860, among others, are modified by the addition of mannose residues [22-25]. This post-translational modification could contribute to virulence, colonization, and invasion of the host cell $[16,22,26,27]$. However, the significance of the $O$-mannosylation of glycoproteins in infection and the host innate immune response is poorly understood. Previously, it has been demonstrated that the $\mathrm{O}$-mannosylation pattern of the alanine and proline-rich protein (APA), which is a immunodominant secreted antigen from $M t b$, determines its activity [24, 28, 29]. Native APA induces a potent, delayed-type hypersensitivity response, and stimulates the priming of T-cells in vitro and in vivo, in contrast to the non-glycosylated recombinant APA produced in $E$. coli $[28,29]$. Moreover, antibodies derived from human TB patients react strongly with the $O$-glycosylated form of APA, whereas the non-glycosylated protein is unable to bind to these antibodies [30]. In addition, it has been suggested that the protective properties of the anti-tuberculosis vaccine are related to the pattern of $O$-mannosylation generated by $M$. bovis bacillus Calmette-Guérin [27-29, 31]. Other $O$-mannosylated proteins are also potent $M t b$ antigens such as PstS-1, LpqH, and LprG [23, 32, 33], in which their glycan structures have been suggested to interact with host receptors, such as DC-SIGN on human dendritic cells [34], Toll-like receptors [35], and mannose receptors [36].

The Mtb phosphate-binding protein PstS-1 (Rv0934, PhoS1 or PBP-1) is an antigenic glycolipoprotein that is produced and secreted by $M t b$. This $38 \mathrm{kDa}$ antigen is composed of 374 amino acids including a signal peptide that is proteolytically removed to generate a mature protein of 351 residues, which is then exported to the outer membrane surface of $M t b$ [37-39]. This antigen belongs to the $\mathrm{ABC}$ type phosphate transport system $[40,41]$ and its accumulation in the cell wall increases in response to an absence of phosphate in the culture medium [41]. Importantly, this protein induces a strong immune response and causes adaptive protective immunity in mice [42, 43] and humans [38, 44]; furthermore, it has been reported to be associated with the active form of TB $[45,46]$. Although it is known that the native antigen is also $O$-mannosylated $[23,36]$, the exact sites of its $\mathrm{O}$-glycosylation remain unclear. Using a predictive tool to analyze several $M t b$ glycoproteins, it has been proposed that PstS-1 has three $O$-glycosylation sites, most probably at threonines 20, 21, and 28 at the $\mathrm{N}$-terminus [47]. To date, the crystallographic structure of native PstS-1 has not been determined.

In yeasts such as $S$. cerevisiae, $O$-mannosylation is also an important post-translational protein modification, playing roles in the composition of cell walls, cellular differentiation, septation and viability in fission yeast, vesicle delivery, and virulence [48-51]. O-linked mannosylation in yeasts occurs through the attachment of mannose glycans to a serine or threonine residue on substrate proteins entering the ER-Golgi pathway, through a series of mannosyltransferases [52-54]. Interestingly, the $O$-mannosylation pathways between yeast organisms and actinomycetes like $M$. tuberculosis are evolutionarily conserved [53]. $O$-mannosylation in actinomycetes, occurs in a manner such that mannose residues are $\alpha-1,2$-linked to serine or threonine residues on proteins residing in bacterial membranes [55-58]. Similarly, in Pichia pastoris, the $O$-linked glycans produced are linear chains of four to five $\alpha-1,2$-linked mannose residues [56, 59], whereas $S$. cerevisiae generates $\alpha-1,2$ and $\alpha-1,3$-linked mannose residues [60-62] in the highly $O$-mannosylated form [53]. Hence, the methylotrophic yeast $P$. pastoris is preferred over $S$. cerevisiae as a heterologous system to produce glycoantigens from $M t b$, because their mannose chains 
are shorter [63], and mimics the modifications performed by $M t b$. This was demonstrated during the production of the antigen rCFP32 in P. pastoris, which, compared with the rCFP32 produced in E. coli, resulting in a rCFP32 protein that was majorly immunoreactive, as assessed by in vitro antibody production and the serum titers from tuberculosis patients [64, 65]. Furthermore, the use of a heterologous system based on the methylotrophic $P$. pastoris results in a high productivity for recombinant proteins under conditions that are free from endotoxins and viral DNA [66-68]. P. pastoris is thereby now considered a safe organism, in which several human biopharmaceuticals have been produced [69].

Thus, with the intention of producing the glycoantigen PstS-1 with post-translational characteristics similar to that of the native antigen produced by $M t b$, and to avoid the use of harmful $M t b$ which requires long cultivation periods, we describe here the production of a non-tagged recombinant $O$-mannosylated glycoantigen PstS-1. This work describes the production on the laboratory scale (shake flasks and bioreactors) of a recombinant form of the O-mannosylated glycoantigen PstS-1 (rPstS-1, 98.9\% sequence identity to the native protein), its purification and characterization, some of its $O$-mannosylation modifications, and its immunological reactivity by sera from patients diagnosed with tuberculosis. The production of this glycoprotein will aid in the study of its immunological activity and will be useful as a diagnostic tool and/or as a vaccine against $\mathrm{TB}$.

\section{Results and discussion}

\section{Development of strains secreting rPstS-1}

The gene sequence encoding $M$. tuberculosis PstS-1 (Rv0934) (GenBank number: P9WGU1) was synthesized, accommodating for the preferential codon usage in P. pastoris $[70,71]$. The synthesized DNA also excluded the nucleotide sequences encoding amino acids 1-21 (MKIRLHTLLAVLTAAPLLLAA) of the 23 amino acids that form the signal peptide. The two amino acids in the signal peptide that were retained were Ala-Gly (22-23). The retention of these avoids lipidation of the Cys residue (residue 24), which would normally be present at the $\mathrm{N}$-terminus of the mature processed protein. Moreover, since two amino acids (N57 and N247), were predicted to be potential $\mathrm{N}$-glycosylation sites (NetNGlyc 1.0.), these residues were substituted with glutamines (N55Q and $\mathrm{N} 247 \mathrm{Q})$ to maintain a conformation similar to that of native PstS-1 [72, 73]. The synthesized coding sequence was then cloned downstream of the $\alpha$-mating factor in the vector pPICZ $\alpha \mathrm{B}$, conserving the open reading frame, and under the control of the $P$. pastoris alcohol oxidase 1 promoter (pAOX1). This promoter is tightly regulated by methanol; however, its transcriptional regulatory mechanism has only partially been described [74]. Induction of the pAOX1 promoter requires the lack of a repressing carbon source, such as glycerol; the depletion of such a carbon source results in a slight de-repression of the promoter. In addition, methanol (the inducible carbon source) causes significant pAOX1 de-repression, normally resulting in production of the enzymes required for methanol utilization [66, 74-76]. Here, rPstS-1 was expressed without tags because these might alter the biological or physicochemical properties compared to native or unlabeled proteins [77-80]. The constructed plasmid was verified by PCR and sequencing. Since P. pastoris $\mathrm{X}$-33 was transformed with this recombinant plasmid, $P$. pastoris $\mathrm{X}-33$ was also transformed with the empty plasmid vector as a control. YPD agar medium supplemented with Zeocin ${ }^{\mathrm{TM}}$ was used to select for recombinant yeasts. The selected clones were cultured in a $50 \mathrm{~mL}$ BMGY culture which was then used to inoculate a $250 \mathrm{~mL}$ culture in BSF, and after $32 \mathrm{~h}$ in BMMY media and following the addition of 5,10 , or $20 \mathrm{~mL} / \mathrm{L}$ of methanol, the growth and production of rPstS-1 were compared. After $60 \mathrm{~h}$ of culture an increase in production of approximately $15-20 \%$ was observed when adding $10 \mathrm{~mL} / \mathrm{L}$ methanol, compared to 5 and $20 \mathrm{~mL} / \mathrm{L}$ of methanol (data not shown). As previously reported, the methanol concentration appears to affect the productivity depending on the clone [81].

\section{Use of baffled shake flasks and bioreactor cultures of $P$. pastoris to produce rPstS-1}

The $P$. pastoris $\mathrm{X}-33$ clone producing $\mathrm{rPstS}-1$ was characterized with regard to its growth in $50 \mathrm{~mL}$ of BMGY in BSFs at $30{ }^{\circ} \mathrm{C}$ and $250 \mathrm{rpm}$. After complete glycerol consumption $(32 \mathrm{~h})$, all the cells were transferred to $50 \mathrm{~mL}$ of BMMY containing $1 \%$ methanol $(10 \mathrm{~mL} / \mathrm{L})$, which was fed every $12 \mathrm{~h}$, and followed until $73 \mathrm{~h}$ post induction. In BMGY media, the maximal biomass reached was $26.6 \pm 0.4$ A.U. $(8.8 \pm 0.2 \mathrm{~g} / \mathrm{L})$, with a pre-induction specific growth rate of $0.323 \pm 0.025 / \mathrm{h}$ (Fig. 1a, Table 1). In BMMY, used to induce rPstS-1 expression, the maximal biomass achieved was $32.7 \pm 0.8$ A.U. $(10.8 \pm 0.3 \mathrm{~g} / \mathrm{L})$ (Fig. 1a, Table 1), with a post-induction specific growth rate of $0.003 \pm 0.001 / \mathrm{h}$ (Table 1). Approximately a $23 \%$ higher level of biomass accumulated after induction. A specific glycerol consumption rate $\left(\mathrm{q}_{\mathrm{s}}\right)$ of $0.021 \pm 0.004$ $\mathrm{g}_{\mathrm{Glyc}} / \mathrm{g}_{\mathrm{DCW}} \mathrm{h}$ and a yield of biomass per glycerol consumed of $0.69 \pm 0.01 \mathrm{~g}_{\mathrm{DCW}} / \mathrm{g}_{\text {glycerol }}$ were obtained. The biomass to methanol yield was $0.051 \pm 0.004 \mathrm{~g}_{\mathrm{DCW}} /$ $\mathrm{g}_{\text {methanol }}$.

The $P$. pastoris $\mathrm{X}-33$ clone producing $\mathrm{rPstS}-1$ was also characterized in bioreactor cultures. For this, a typical feeding profile for a carbon source was used; this started with a batch culture in glycerol (BMGY), and when an increase in the dissolved oxygen tension (DOT) 


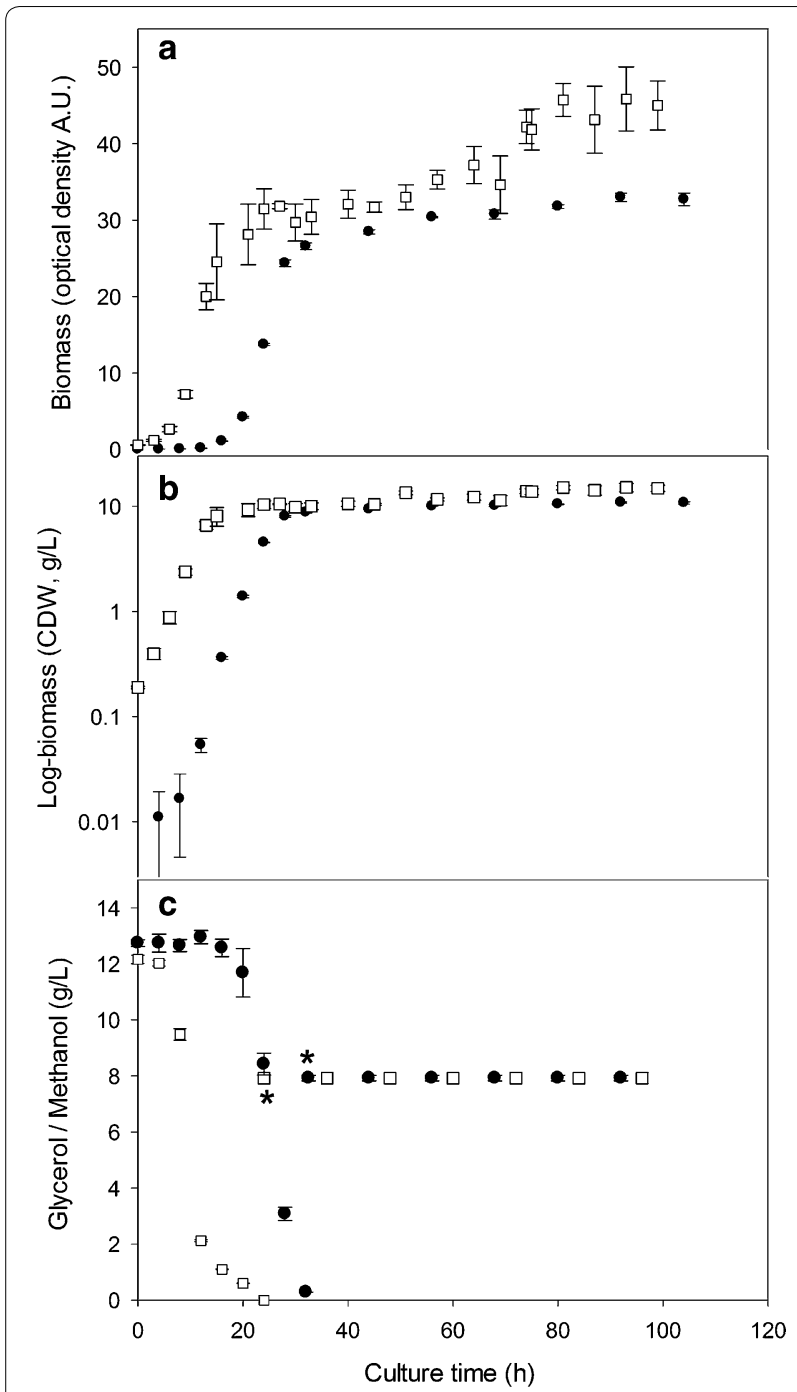

Fig. 1 Kinetic growth of the recombinant strain P. pastoris producer of rPstS-1 measure as optical density (a) and dry weight (b) and carbon source consumption (c), batch phase glycerol was measured and the feeding by methanol was also shown (start of feeding/ induction was marked, upper asterisk for baffled shake flasks, down asterisk for bioreactor), in baffled shake flask (close dots) and controlled bioreactor (open squares)

was observed (as a result of the exhaustion of the carbon source), the methanol fed-batch phase was started. This strategy was followed to avoid methanol accumulating to high levels, which could cause the accumulation of formaldehyde to toxic levels [82, 83]. Using glycerol as a carbon source, a maximal biomass of $10.4 \pm 0.9 / \mathrm{gL}$ was obtained (Fig. 1, Table 1). Glycerol depletion was observed after $24 \mathrm{~h}$ of culture. After consumption of the glycerol, methanol feeding $(10 \mathrm{~mL} / \mathrm{L})$ was performed every $12 \mathrm{~h}$ to induce expression of the rPstS-1 (Fig. 1c). A maximal biomass of $15.5 \pm 0.9 / \mathrm{gL}$ was obtained at the end of the culture, achieving around a 49\% higher biomass level following the addition of methanol (Table 1).

A comparison between the BSFs and bioreactor cultures showed there to be similar specific growth rates during the P. pastoris X-33 (rPstS-1) batch growth phase in the glycerol containing culture medium, which is similar to previously reported results $[84,85]$. However, during the methanol induction phase, the specific growth rate double in the bioreactors compared to the BSFs. Additionally, the maximal biomass reached in the bioreactors was higher in both BMGY and BMMY, being around 19 and $43 \%$ higher, respectively, compared to that in the BSFs (Table 1). This might be caused by the limited oxygen transfer in the BSFs compared to the bioreactor cultures [86-88], thereby affecting the post-induction specific growth rate [83]. Differences in biomass/glycerol yield were also observed, with a $17 \%$ lower in the BSFs compared to the bioreactor cultures. Moreover, the yields obtained in this study are in agreement with those reported by Chiruvolu et al. [89], who reported values between 0.70 and $0.78 \mathrm{~g}_{\mathrm{DCW}} / \mathrm{g}_{\mathrm{Glyc}}$ for bioreactors without $\mathrm{pH}$ control and $0.62 \mathrm{~g}_{\mathrm{DCW}} / \mathrm{g}_{\mathrm{Glyc}}$ in shake flasks. No significant differences were observed in glycerol consumption rate $\left(\mathrm{q}_{\mathrm{s}}\right)$ between the bioreactor and BSF cultures.

\section{Production of rPstS-1, its characterization by SDS-PAGE, and immunodetection}

At the end of the BSFs culture, the total protein content of the supernatant was $127 \pm 15 \mathrm{mg} / \mathrm{L}$. A densitometric analysis of the secreted proteins by SDS-PAGE (Fig. 2a) showed that the rPstS-1 protein $(\sim 38 \mathrm{kDa})$ represented $\sim 36 \%(46 \pm 5 \mathrm{mg} / \mathrm{L}$, Table 1$)$ of the total secreted protein. After the induction in the BSFs, relatively low-levels of extracellular host proteins were detected (Fig. 2a, time 0 post-induction), which is one advantage of producing recombinant proteins in P. pastoris $[66,90]$.

After $72 \mathrm{~h}$ of induction with methanol in the bioreactor cultures, the total protein content of the supernatant was $185 \pm 9 \mathrm{mg} / \mathrm{L}$ (Table 1 ). The level of secreted rPstS-1 in the supernatant was $46 \pm 4 \mathrm{mg} / \mathrm{L}$ (Fig. 2b, Table 1). To confirm the identity of rPstS-1, the supernatant was analyzed by a western blot assay using a polyclonal antibody anti-pstS1 (Fig. 2c). The $38 \mathrm{kDa}$ protein was confirmed to be rPstS- 1 and interestingly, there were no apparent sign of protein degradation, nor was $\mathrm{rPstS}-1$ detected in the supernatant before methanol induction (Fig. 2c).

It is important to note that although there was a $69 \%$ higher level of total protein in the supernatant produced in the bioreactors compared to the BSFs, the absolute levels of rPstS- 1 were similar ( $46 \pm 5$ and $46 \pm 4 \mathrm{mg} / \mathrm{L}$, in the BSFs and bioreactor, respectively). As a result, there was a decrease in the specific production rate of $\mathrm{rPstS}-1$ in the bioreactors (32\% lower than the BSFs, Table 1), while 
Table 1 Stoichiometric and kinetic parameters of $P$. pastoris growth and rPstS-1 production cultured in baffled shake flasks and in $1.0 \mathrm{~L}$ bioreactors

\begin{tabular}{|c|c|c|}
\hline Parameter & Baffled shake flask & Bioreactor \\
\hline Max O.D. 600 nm glycerol (A.U.) & $26.5 \pm 0.4$ & $31.5 \pm 2.2^{b}$ \\
\hline Max O.D. 600 nm methanol (A.U.) & $32.7 \pm 0.8$ & $47.0 \pm 2.6^{a}$ \\
\hline Max biomass glycerol (g/L) & $8.8 \pm 0.2 \mathrm{~g} / \mathrm{L}$ & $10.4 \pm 0.9^{b}$ \\
\hline Max biomass methanol (g/L) & $10.8 \pm 0.3 \mathrm{~g} / \mathrm{L}$ & $15.5 \pm 0.9^{\mathrm{a}}$ \\
\hline u glycerol (/h) & $0.323 \pm 0.025$ & $0.286 \pm 0.033$ \\
\hline$\mu$ methanol (/h) & $0.003 \pm 0.001$ & $0.006 \pm 0.001^{b}$ \\
\hline$Y_{x / s}\left(g_{D C W} / g_{G l y c}\right)$ & $0.69 \pm 0.01$ & $0.81 \pm 0.03^{b}$ \\
\hline$Y_{x / s}\left(g_{D C W} / g_{M e t h}\right)$ & $0.051 \pm 0.004$ & $0.092 \pm 0.004^{\mathrm{a}}$ \\
\hline $\mathrm{q}_{\mathrm{s}}\left(\mathrm{g}_{\mathrm{Glyc}} / \mathrm{g}_{\mathrm{DCW}} \mathrm{h}\right)$ & $0.021 \pm 0.004$ & $0.034 \pm 0.013$ \\
\hline Supernatant total protein $(\mathrm{mg} / \mathrm{L})$ & $127 \pm 15$ & $185 \pm 9^{\mathrm{a}}$ \\
\hline$Y_{\text {STP/DCW }}\left(m_{\text {STP }} / g_{\text {DCW }}\right)$ & $11.75 \pm 1.13$ & $11.92 \pm 0.59$ \\
\hline rPstS-1 (mg/L) & $46 \pm 5$ & $46 \pm 4$ \\
\hline $\mathrm{q}_{\mathrm{rPstS}-1}(\mathrm{mg} / \mathrm{L} \mathrm{h})$ & $0.639 \pm 0.070$ & $0.633 \pm 0.054$ \\
\hline $\mathrm{q}_{\mathrm{p}(\mathrm{rPstS}-1)}\left(\mathrm{mg}_{\mathrm{rPstS}-1} / \mathrm{g}_{\mathrm{DCW}} \mathrm{h}\right)$ & $0.059 \pm 0.002$ & $0.040 \pm 0.004^{\mathrm{a}}$ \\
\hline$Y_{\text {rPstS-1/x }}\left(\mathrm{mg}_{\mathrm{rPstS}-1} / \mathrm{g}_{\mathrm{DCW}}\right)$ & $3.3 \pm 0.01$ & $4.0 \pm 0.02^{\mathrm{a}}$ \\
\hline
\end{tabular}

The mean and standard deviation for at least three biological replicates are shown

O.D., optical density; A.U., absorbance units; $\mu$, specific growth rate; STP, supernatant total protein; DWC, dry cell weight; $\mathrm{Y}_{x / s,}$ total dry cell weight yield per glycerol; $\mathrm{Y}_{\mathrm{x} / \mathrm{s}^{\prime}}$ total dry cell weight yield per methanol; $\mathrm{Y}_{\text {STP/DCW, }}$ STP yield per DCW; $q_{s^{\prime}}$ specific consumption rate of glycerol per DCW; $q_{p_{s t 5}-1}$, volumetric productivity of rPstS-1; $q_{p(r P s t s-1)}$, specific productivity of rPstS-1; $Y_{r P s t-1 / x^{\prime}}$ PstS-1 yield per DCW. $\mu$ was calculated in first $8 \mathrm{~h}$ of culture

$p$ value was calculated using $t$ test by comparing the results of Shake flask VS Bioreactor

${ }^{\mathrm{a}} p<0.005 ;{ }^{\mathrm{b}} p<0.05$

the volumetric production rate of rPstS-1 in both systems was the same (Table 1). The level of accumulation of the folded rPstS-1 protein in P. pastoris was almost three times higher per liter compared to previous published bacterial system [91].

\section{Purification of rPstS-1 from supernatants}

Purification of rPstS- 1 from the P. pastoris bioreactor culture supernatant was carried out by ultrafiltration, which is often used as an alternative method to the affinity chromatography procedures used for tagged proteins and does not require any refolding steps, in comparison with other bioprocesses $[91,92]$. Thus, rPstS-1 was purified in a three-step procedure: first, the culture was clarified by tangential filtration $(100 \mathrm{kDa})$; then, the supernatant was subjected to another tangential filtration $(10 \mathrm{kDa})$; and finally, RP-HPLC was used. The two tangential filtrations gave recoveries of $41 \%$ and $29 \%$, respectively (Table 2 ). After the RP-HPLC step, a recovery of $4 \mathrm{mg} / \mathrm{L}$ of rPstS-1, with a purity of $98 \%$ was obtained, with a retention time of 20 min, eluting in $\mathrm{H}_{2} \mathrm{O}$ :ACN:TFA (50:50:0.1) (Fig. 3c). Furthermore, the purification steps were monitored by SDS-PAGE (Fig. 3a), and the densitometric analysis

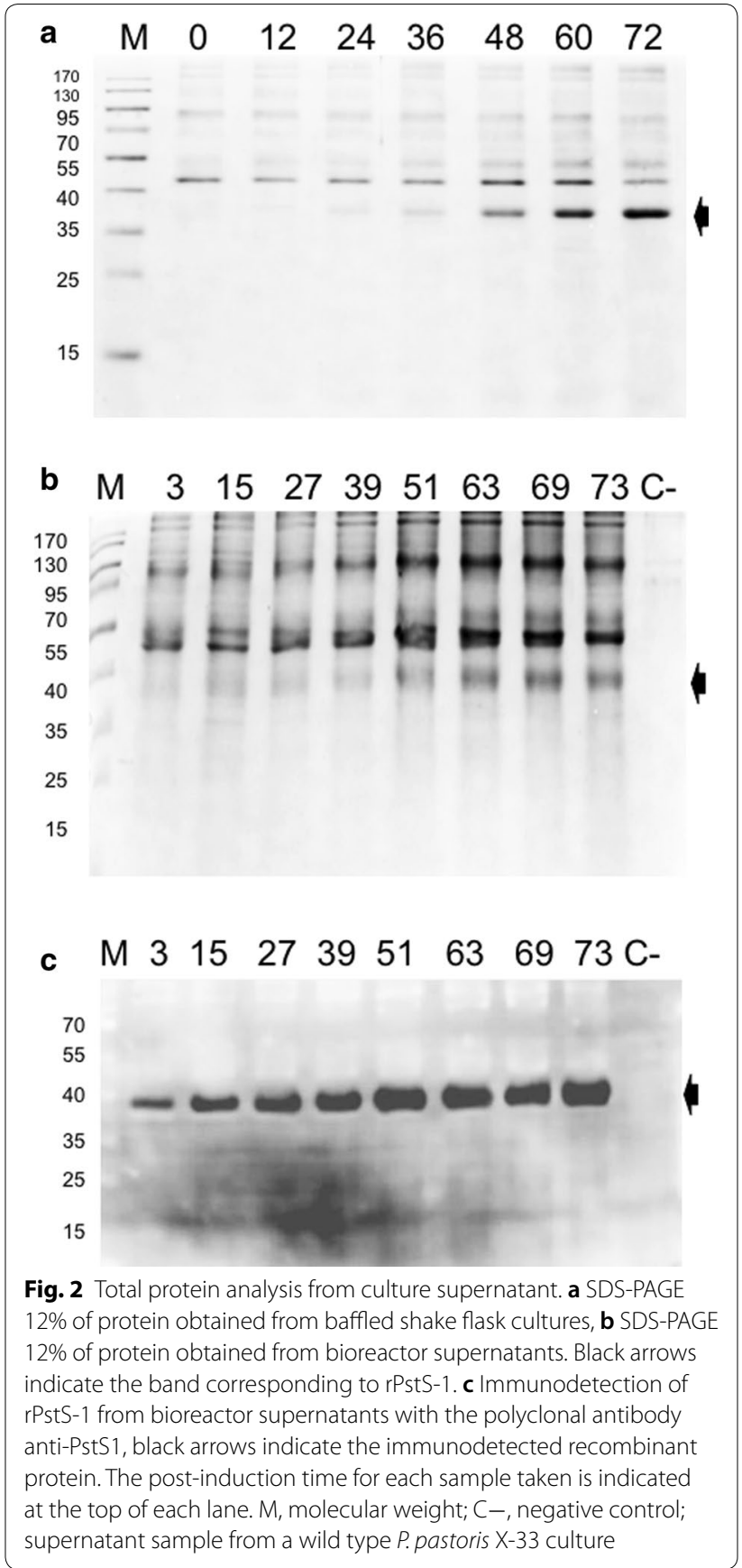

of SDS-PAGE showed a purity of up to $90 \%$ for rPstS-1 after the final step (Fig. 3a, line 4). Also, the presence of rPstS-1 during the different purification steps was followed by western blot (Fig. 3b). This study clearly demonstrates the utility of tangential filtration technology to purify $O$-mannosylated rPstS-1 without affinity tags, from a $P$. pastoris culture supernatant. It should be noted that the technology presented here is scalable and can be applied for the large-scale production of rPstS-1 and other $M t b$ antigens produced in a similar fashion. 
Table 2 Summary of purification of rPstS-1

\begin{tabular}{lcccc}
\hline Purification stage & $\begin{array}{l}\text { Recovery of total protein } \\
(\mathbf{m g} / \mathbf{L})^{\mathbf{a}}\end{array}$ & rPsts-1 (mg/L) & Recovery \% & Purity \% \\
\hline Total protein from supernatant & $185 \pm 9$ & $46 \pm 4$ & 100 & $25 \pm 3$ \\
Ultrafiltration (> 100 kDa) & $80.0 \pm 2.9$ & $18.9 \pm 5.0$ & $41.0 \pm 14.9$ & $23.5 \pm 5.4$ \\
Ultrafiltration (100-10 kDa) & $49.0 \pm 3.4$ & $13.2 \pm 4.2$ & $28.6 \pm 7.1$ & $26.5 \pm 6.7$ \\
Reverse phase chromatography & $4.3 \pm 0.2$ & $4.2 \pm 0.2$ & $9.1 \pm 1.1$ & $97.7 \pm 0.6$ \\
\hline
\end{tabular}

${ }^{a}$ Total supernatant protein was calculated by Bradford method. The rPstS-1 protein was calculated by densitometry in gel after each stage of purification, and each protein purification step was calculated per liter of initial cell culture volume

\section{Structural conformation of rPstS-1}

The secondary structure of rPstS-1 was determined using far-UV circular dichroism (CD) spectroscopy. At both the rPstS-1 concentrations tested, the spectra obtained at $25^{\circ} \mathrm{C}$ showed a maximum negative peak at $207 \mathrm{~nm}$, in addition to a broad peak between 212 and $219 \mathrm{~nm}$, and a positive peak at $197 \mathrm{~nm}$, (Fig. 4). A molar ellipticity of $-4916.67 \mathrm{deg}^{*} \mathrm{~cm}^{2 *} / \mathrm{dmol}$ was obtained for rPstS-1 at $0.125 \mathrm{mg} / \mathrm{mL}$ and $-4209.29 \mathrm{deg}^{*} \mathrm{~cm}^{2 *} / \mathrm{dmol}$ for rPstS-1 at $0.250 \mathrm{mg} / \mathrm{mL}$ concentration. Analysis of the CD spectrum of rPstS-1 using CAPITO [93] showed a secondary structure consisting of $10 \% \alpha$-helix, $38 \%$ beta sheets, and $56 \%$ disordered structures for rPstS- 1 at $0.125 \mathrm{mg} / \mathrm{mL}$. Moreover, at $0.250 \mathrm{mg} / \mathrm{mL}$ rPstS- 1 the spectrum showed $5 \% \alpha$-helix, $40 \% \beta$-sheets, and $53 \%$ disordered structures (Fig. 4, Table 3). The high content of $\beta$-sheets is in agreement with the $\mathrm{CD}$ spectrum of the purified native denaturated and refolded $38 \mathrm{kDa}$ protein obtained from a H37Rv culture, which showed a negative broad peak at $212 \mathrm{~nm}$ and a positive peak at $190 \mathrm{~nm}$, suggesting a high $\beta$-sheet content [12].

On the other hand, the spectra of rPstS-1 produced in E. coli showed a maximum negative peak at $209 \mathrm{~nm}$ with a broad peak around $218 \mathrm{~nm}$ at both protein concentrations (Fig. 4). The rPstS-1 expressed in E. coli showed an increased $\alpha$-helix content $(16 \% \alpha$-helix at $125 \mu \mathrm{g} / \mathrm{mL}$ and $20 \% \alpha$-helix at $250 \mu \mathrm{g} / \mathrm{mL}$, Fig. 4, Table 3).

The data obtained in this study show peaks that are similar to those in the $\mathrm{CD}$ spectrum obtained from the recombinant $38 \mathrm{KDa}$ reference antigen from the WHO bank, which has negative peaks at $208 \mathrm{~nm}$ and $225 \mathrm{~nm}$ [12], and also the spectrum from the full length rPstS-1 expressed in $E$. coli which also shows negative peaks at $208 \mathrm{~nm}$ and $218 \mathrm{~nm}$, in addition to a positive peak at $190 \mathrm{~nm}$ [92]. However, an analysis of the rPstS-1 secondary structure using CDNN software showed that rPstS-1 expressed in E. coli had a conformation consisting of $40 \% \alpha$-helices and $8.9 \%$ antiparallel and $5.6 \%$ parallel $\beta$-sheets [93]. In addition, the data obtained from the X-ray structure of rPstS-1 expressed in E. coli showed a composition of $34 \% \alpha$-helices, $18 \%$ beta sheets, and $41 \%$ disordered structures (PDB accession No. 1PC3) [94].
The CD spectrum of rPstS-1 produced in E. coli points to a predominant $\alpha$-helix peak ( $208 \mathrm{~nm}$ ), which differs from the secondary structure suggested by the spectrum of the purified, denaturated, and refolded native $38 \mathrm{kDa}$ antigen from H37Rv [12]. These differences might arise due to the tags added, the purification steps used, or the refolding process used for proteins expressed in E. coli. The data obtained in this study suggest that the secondary structure of rPstS-1 produced in P. pastoris differs from that produced in bacteria. Moreover, the rPstS-1 produced here has a $\beta$-sheet conformation that agrees with that observed for the native protein [12]. This is probably related to the $O$-mannosylation of rPstS- 1 , which is similar to the native protein expressed in M. tuberculosis which has approximately a $1 \%$ carbohydrate content [36]. Moreover, the rPstS-1 produced in P. pastoris was in a soluble form, thereby avoiding the need for a refolding step, which is needed for many proteins produced in $E$. coli. An understanding of how $O$-mannosylation affects the protein conformation is important to establish whether this modification is an important parameter for the correct folding of a protein.

\section{Mass spectrometry analysis of the rPstS- 1 antigen}

The full amino acid sequence of the PstS-1 gene product deduced from the sequence of the $M t b$ consists of 374 residues, with a theoretical MW of 38,243 Da (UniProtKB P9WGU1). The first 23 amino acid residues form a signal peptide, which directs lipidation at the $\mathrm{N}$-terminus [37]. In this study, rPstS-1 was produced without the first 21 amino acids to avoid lipidation, so the recombinant protein had a predicted MW of $36,059.36 \mathrm{Da}$, and this in agreement with the peak shown in Fig. 5a. A zoomed view of the peak (Fig. 5a inset) shows a family of different isoforms, probably arising to different posttranslational modifications (PTMs), that might correspond to the attachment of hexose units, along with other types of modifications. It is worth mentioning that in the native PstS-1, the $O$-mannosylation pattern sites and the number of mannose units have not been determined. A prediction program (Glycopp v1.0) [95] for prokaryotic glycosides indicated that there were 26 
a

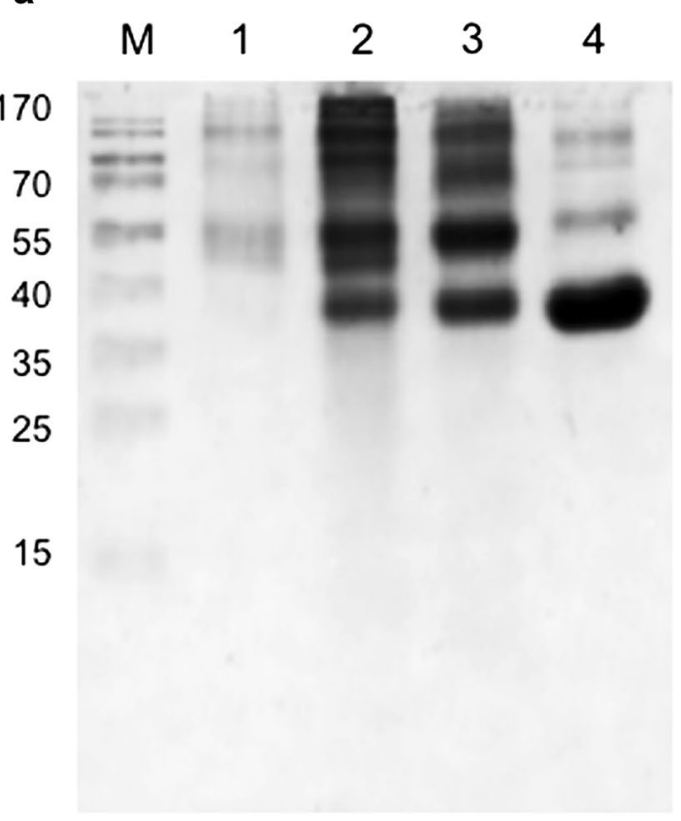

b

$1 \quad 2 \quad 3 \quad 4$

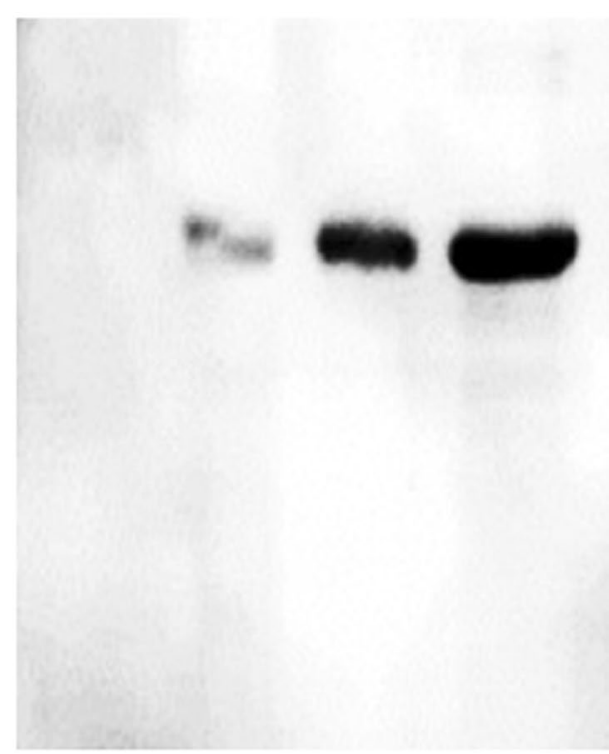

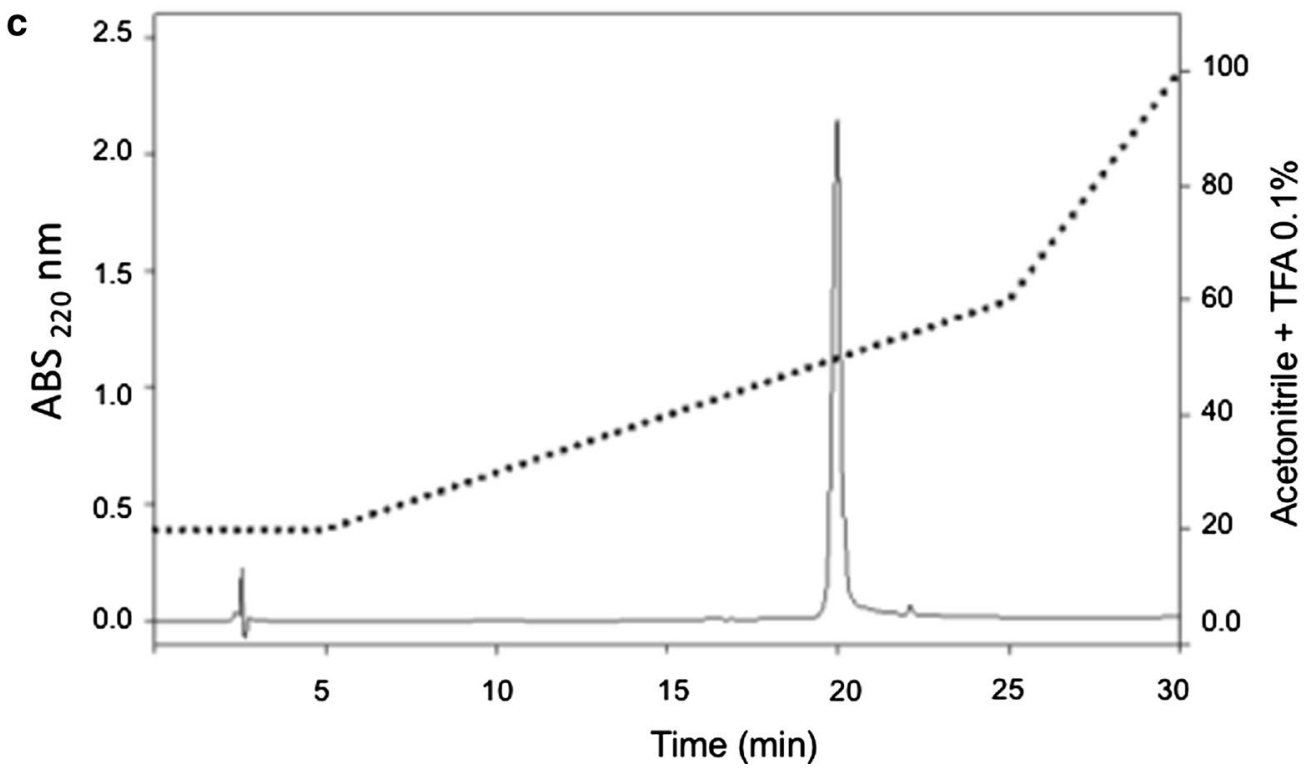

Fig. 3 Purification of rPstS-1. a SDS-PAGE 12\% during purification process. b Immunodetection of protein obtained by ultrafiltration and RP-HPLC. c Separation of components obtained after tangential filtration in a XBridge Protein BEH C4 reverse-phase column, from which the component eluting at 20 min was shown to be homogeneous. The gradient started by 5 min at $20 \%$ of B, then separation was run from 20 to $60 \%$ solution B, over next $20 \mathrm{~min}$, and the pure rPstS-1 eluted at $20.74 \mathrm{~min}$. Lanes M: molecular weight marker; 1, total protein from supernatant of the $27 \mathrm{~h}$ growth in BMGY; 2, total protein from supernatant obtained after $72 \mathrm{~h}$ under induction; 3, 10-100 kDa protein cut off from tangential filtration; 4, protein purify by RP-HPLC

possible $O$-glycosylation sites in rPstS-1, with nine sites being localized at the $\mathrm{N}$-terminus (in the first 25 amino acids).

In order to analyze the rPstS- 1 amino acid sequence and $O$-mannosylation, rPstS-1 was digested with the enzymes Lys- $\mathrm{C}$ or trypsin. The resulting peptides were analyzed by matrix assisted laser desorption ionization time-of-flight (MALDI-TOF) spectrometry. The theoretical fragment profile expected for trypsin or Lys-C digestion and the results obtained are shown in Tables 4 and 


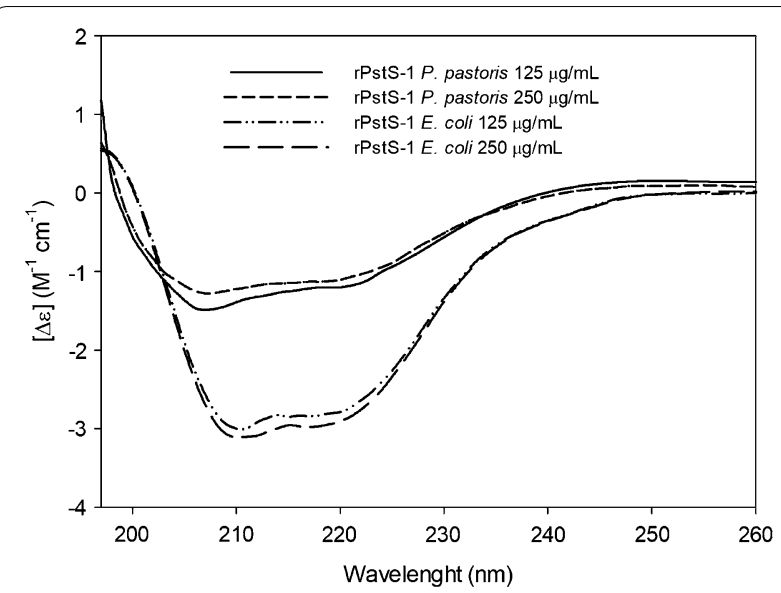

Fig. 4 Structural analysis of rPstS-1 from P. pastoris and E. coli purified by HPLC by Circular dichroism spectrum scanned over 190-260 nm range at 125 and $250 \mu \mathrm{g} / \mathrm{mL}$

Table 3 Secondary structure of rPstS-1 from $P$. pastoris and $E$. coli. Comparative secondary structure content obtained by CD data analysis, NMR data and CAPITO server

\begin{tabular}{|c|c|c|c|c|c|}
\hline & \multirow{3}{*}{$\begin{array}{l}\text { NMR [94] } \\
\text { PDB: } \\
\text { 1PC3 }\end{array}$} & \multicolumn{4}{|c|}{ CAPITO (CD) } \\
\hline & & \multicolumn{2}{|c|}{ rPstS-1 from E. coli } & \multicolumn{2}{|c|}{$\begin{array}{l}\text { rPstS-1 from } P \text {. } \\
\text { pastoris }\end{array}$} \\
\hline & & $\begin{array}{l}125 \mu \mathrm{g} / \\
\mathrm{mL}\end{array}$ & $\begin{array}{l}250 \mu \mathrm{g} / \\
\mathrm{mL}\end{array}$ & $\begin{array}{l}125 \mu \mathrm{g} / \\
\mathrm{mL}\end{array}$ & $250 \mu \mathrm{g} / \mathrm{mL}$ \\
\hline Helix (\%) & 34 & 16 & 20 & 10 & 5 \\
\hline $\begin{array}{l}\beta \text {-strand } \\
(\%)\end{array}$ & 18 & 28 & 29 & 38 & 40 \\
\hline $\begin{array}{l}\text { Irregular } \\
\text { (\%) }\end{array}$ & 41 & 50 & 52 & 56 & 53 \\
\hline
\end{tabular}

CAPITO CD Analysis \& Plotting Tool [93], CD circular dichroism, NMR, nuclear magnetic resonance; $P D B$ protein data bank

5 , respectively. The peaks obtained from the digestions covered $83 \%$ of the sequence. These results indicate that the amino acids comprising to positions 55 to 97 and 138 to 342 were not modified by the addition of mannose residues. Around $20 \%$ of the peptide sequence obtained by MS/MS is presented in Additional file 1: Figure S1. In contrast, the N-terminal sequence formed by the first 97 amino acids (P1T) was not detected in either the peptides formed by trypsin digestion (P4T, P8T and P12T), or in those formed by Lys-C digestion (P1, P2, P3, P4, P5, P6, P11, and P12) (Table 5). This could probably be due to a lack of ionization, the inherent hydrophobicity of the peptides, or the presence of hexose residues.

The peptide that was found to be mannosylated was P3T (aa. 98-123: GLMNIALAISAQQVNYNLPGVSEHLK) which is located near the N-terminus, with 2, 4 , and 5 mannose residues indicated by the addition of
162 Da per hexose (Fig. 5b, c; Tables 4, 5). In addition, P5T (aa. 128-138: VLAAMYQGTIK) was also found to have 6 hexose residues (Fig. 5b); whereas, P15T at the C-terminus (aa. 343-353: LSDALIATI $\underline{S}$ ) was found to have 4 hexose residues attached (Fig. 5b). These three peptides contained serine or threonine residues (underlined), in accordance with them containing potential $\mathrm{O}$-glycosylation sites (regions rich in $\mathrm{S}$ or $\mathrm{T}$ ) as has been proposed to occur in S. cerevisiae. Attachment of the mannose residues appears to be performed in part by the protein-O-mannosyltransferase (PMT), which is conserved in yeasts and is similar to the enzymes found in $P$. pastoris $[96,97]$.

\section{rPsts-1 sero-reactivity with human sera samples}

With the intention of confirming the similarity of rPstS-1 to the $38 \mathrm{kDa}$ native antigen, the sero-reactivity of rPstS-1 was assessed using an ELISA method. This was carried out using human serum samples from patients with clinically confirmed active $\mathrm{TB}$, and compared with sera from subjects with both positive and negative PPD test, which did not present any clinical evidence of active TB. Thirty sera from patients with active TB (these characteristics are described in methods) showed a statistically positive response against the rPstS-1 produced in P. pastoris, compared with the positive and negative PPD groups (Fig. 6). To confirm the significance of the glycosylation pattern of $\mathrm{rPstS}-1$ produced in P. pastoris, the sero-reactivity of the non-glycosylated rPstS-1 version produced by E. coli cultures [23] was also determined. The recognition of the rPstS-1 from $P$. pastoris by serum from IgG2 in patients with active tuberculosis were 3.2 and 3.5 -fold higher (mean values) than the PPD-negative and PPD-positive subjects, respectively (Fig. 6). Importantly, rPstS-1 produced in $P$. pastoris showed a statistically significant $(P<0.05) 2.0$-fold (mean) higher recognition compared with the non-glycosylated His-tagrPstS-1 produced in E. coli (Fig. 6). Recognition by IgG2 was used in this study, because it is known that it recognizes carbohydrates and protein antigens from bacteria $[98,99]$. The recognition of $P$. pastoris $\mathrm{rPstS}-1$ by sera from patients with $\mathrm{TB}$ suggested that the recombinant protein has a conformation close to the native protein. This might be related to the $O$-mannosylation of rPstS-1 that could improve recognition by TB serum compared to the recognition of the non-glycosylated rPstS-1 produced in $E$. coli. In other previously reported sero-reactivity experiments the detection of the rPstS-1 produced in E. coli, by antibodies derived from patients with TB varied from 36 to $77 \%$ [92, 100, 101], probably due to the lack of glycosylation of the protein.

Up until now, different diagnostic kits such as the PPD skin test or the QuantiFERON ${ }^{\circledR}$-TB test have been 


\section{(See figure on next page.)}

Fig. 5 MALDI-TOF spectra of HPLC purified rPstS-1 antigen. a Non-digested samples were placed on a CHCA (a-Cyano-4-hydroxycinnamic acid) matrix and analyzed in a matrix assisted laser desorption ionization time-of-flight (MALDI-TOF, Bruker Microflex) equipment with a 20-Hz nitrogen laser at I=337 $\mathrm{nm}$. Spectra was recorded in linear positive mode for the mass range 20,000 to 100,000 Da. b MALDI-TOF-MS analysis (linear mode) of a tryptic digest of rPstS-1, sample mixed with a-cyano-4-hydroxycinnamic acid matrix. c MALDI-TOF-MS analysis (linear mode) of a tryptic digest of rPstS-1, sample mixed with a-cyano-4-hydroxycinnamic acid and 3,5-dimethoxy-4-hydroxycinnamic acid matrices. $\mathbf{d}$ MALDI-TOF-MS analysis (linear mode) of a Lys-C digest of rPstS-1. Tryptic and Lys-C peptides marked denote mass peaks corresponding to predicted peptides shown in Tables 4 and 5, respectively. Mannose residues were detected with differences to theoretical and experimental data of 162 Da mark as Hex. All detections are presented in Table 4 and 5

developed, which are $\mathrm{T}$ cell based immune assays, and they do not distinguish between latent and active tuberculosis. The development of sero-diagnostic test using secreted protein antigens derived from $M t b$, such as PstS-1, has been proposed. This is because these antigens are recognized by the TB patients' antibodies with high sensitivity and so this should aid in the development of sensitive diagnostics to distinguish between the inactive and active TB states [101-103].

To qualitatively estimate the antibody avidities for $P$. pastoris rPstS-1 and E. coli expressed His-tag-rPstS-1, we carried out western blot experiments [64] using a rabbit anti-Mycobacterium tuberculosis-PstS-1 polyclonal antibody and a human serum sample from a patient with clinically confirmed active TB. Additional file 2: Figure S2A shows that the anti-PstS-1 polyclonal antibody reacted strongly towards the $P$. pastoris rPstS-1 compared with the E. coli expressed His-Tag-rPstS-1. The relative band intensities (measured by densitometry), of 2.0 and $1.0 \mu \mathrm{g}$ of P. pastoris rPstS-1 appeared to be 3.9 and 5.1 times higher than $E$. coli His-tag-rPstS-1, respectively, suggesting an increased immunoreactivity toward the $O$-mannosylated rPstS-1.

On the other hand, the relative band intensities for the human serum reactivity toward 2.0 and $1.0 \mu \mathrm{g}$ of $P$. pastoris rPstS-1 appeared to be 2.5 and 1.2 times higher than E. coli His-tag-rPstS-1, respectively (note the band of around $38 \mathrm{KDa}$, Additional file 2: Figure S2B). Although, recognition of a protein with a high molecular weight in the P. pastoris rPstS-1 sample was observed, in the $2.0 \mu \mathrm{g}$ E. coli $\mathrm{rPstS}-1$ sample a protein of around $10 \mathrm{KDa}$ was also detected, indicating there is low cross-reactivity between the experiments. The higher detection of $P$. pastoris rPstS-1 compared with E. coli $\mathrm{rPstS}-1$ is probably due to posttranslational differences in the P. pastoris produced protein.

\section{Conclusions}

In this work, using Pichia pastoris as the heterologous host, we achieved the synthesis and production of an untagged recombinant $O$-mannosylated rPstS-1 antigen, containing all the predicted B-cell epitopes.
Under the BSF and bioreactor culture conditions tested, we were able to achieve an accumulation of around $46.2 \pm 4.4 \mathrm{mg} / \mathrm{L}$, which is three times more protein per liter compared to bacterial systems. Furthermore, we have shown the recovery and purification of rPstS-1 using a simple and efficient procedure, finally obtaining $4 \mathrm{mg} / \mathrm{L}$ rPstS-1 with $98 \%$ purity, after three purification steps, and without any need for a refolding step. The circular dichroism spectra of rPstS-1 produced in $P$. pastoris showed that there were differences with the structure reported for this protein produced in bacteria; the $O$-mannosylated rPstS- 1 here had a high $\beta$-sheet content similar to the purified native $38 \mathrm{kDa}$ PstS-1 recovered from a culture filtrate from M. tuberculosis H37Rv. Moreover, the conformational similarity of the O-mannosylated $\mathrm{rPstS}-1$ produced to that of the native antigen $(38 \mathrm{kDa})$, was confirmed indirectly by its ability to be recognized by antibodies derived from the sera of patients positive for tuberculosis, compared to the purified nonglycosylated version (His-tag-rPstS-1) produced in $E$. coli. The detection of $O$-mannosylated rPstS- 1 by active TB serum, emphasizes the potential utility of this antigen for the development of a sensitive sero-diagnostic kit for TB detection using the P. pastoris recombinant system.

\section{Methods}

\section{Reagents and strains}

For culture media components, peptone, yeast extract, and agar were purchased from Difco ${ }^{\mathrm{TM}}$ (Becton-Dickinson, Franklin Lakes, NJ, USA), methanol, peptone, dextrose, and salts were from JT Baker (Phillipsburg, NJ, USA), and sorbitol and Triton X-100 were obtained from Merck (Billerica, MA, USA). For molecular biology reagents, Zeocin $^{\mathrm{TM}}$, T4 ligase, and PCR reagents were purchased from Thermo Fisher Scientific (Waltham, MA, USA), the PstI and KpnI restriction enzymes were purchased from Jena Bioscience GmbH (Jena, Germany), and the plasmid purification kit Zyppy ${ }^{\mathrm{TM}}$ Plasmid Miniprep Kit was bought from Zymo Research (Irvine, CA, USA). Protein precipitation, SDS-PAGE and western blotting reagents were purchased from Merck, and the Super Signal ${ }^{\circledR}$ West Pico Chemiluminescent substrate 


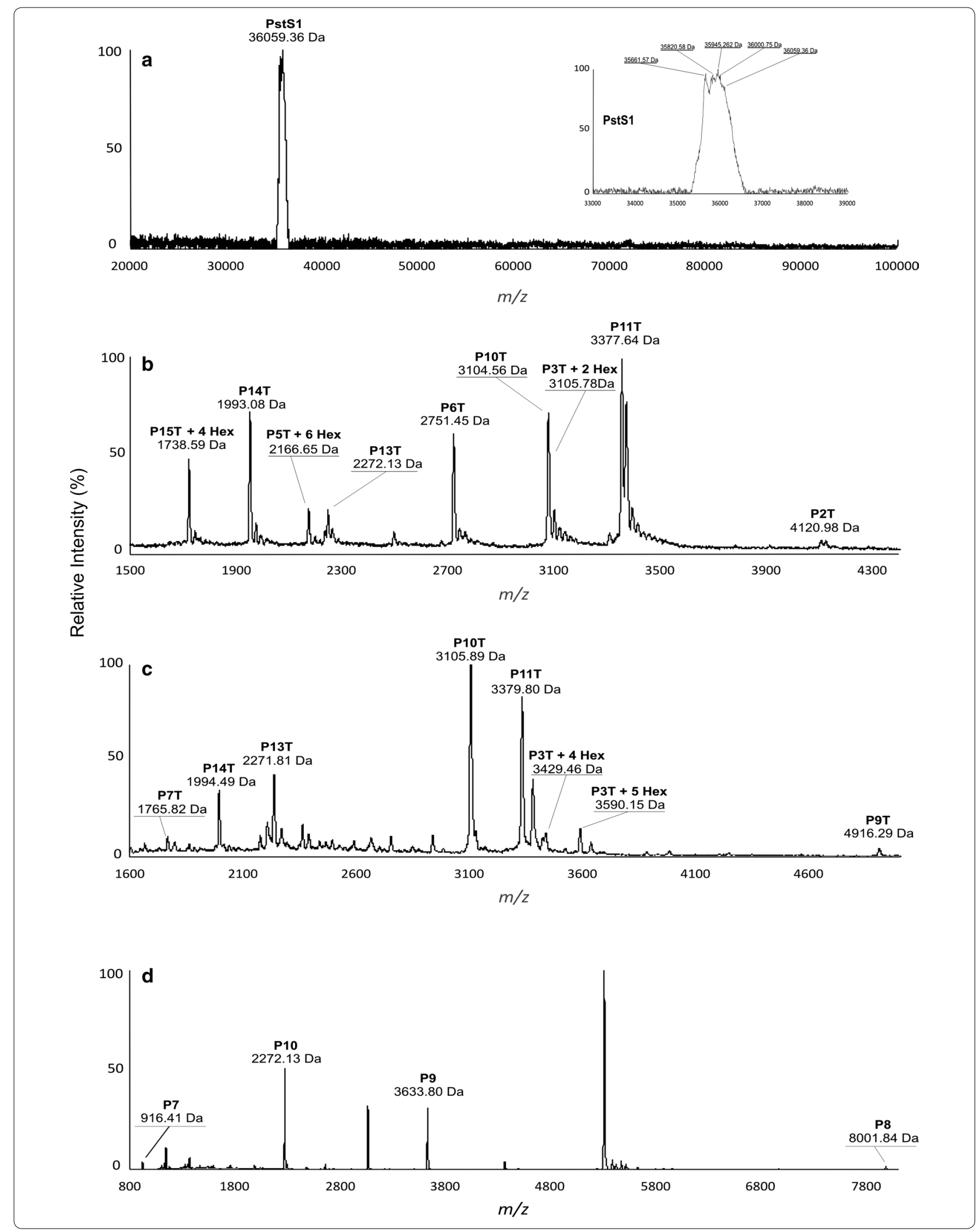


Table 4 Theoretical and obtained peptides mass generated by Trypsin digestion of rPstS-1 produced in P. pastoris

\begin{tabular}{|c|c|c|c|c|c|c|}
\hline Peptide name & $\begin{array}{l}\text { Position } \\
\text { of cleavage } \\
\text { site }\end{array}$ & Peptide & Length (aa) & $\begin{array}{l}\text { Theoretical } \\
\text { Peptide mass } \\
\text { (Da) }\end{array}$ & Modification & Peptide mass (Da) \\
\hline P1T & 54 & $\begin{array}{l}\text { AGCGSKPPSGSPETGAGAGTVATTPASSPVTLA } \\
\text { ETGSTLLYPLFNLWGPAFHER }\end{array}$ & 54 & 5315.900 & & ND \\
\hline $\mathrm{P} 2 \mathrm{~T}$ & 97 & $\begin{array}{l}\text { YPQVTITAQGTGSGAGIAQAAAGTVNIGASDAYL } \\
\text { SEGDMAAHK }\end{array}$ & 43 & 4122.489 & & B) 4120.98 \\
\hline P3T & 123 & GLMNIALAISAQQVNYNLPGVSEHLK & 26 & $\begin{array}{l}2781.222 \\
+2 \text { Hex } 3105.22 \\
+4 \text { Hex } 3429.22 \\
+5 \text { Hex } 3591.22\end{array}$ & $\begin{array}{l}\mathrm{P} 3 \mathrm{~T}+2 \mathrm{Hex} \\
\mathrm{P} 3 \mathrm{~T}+4 \mathrm{Hex} \\
\mathrm{P} 3 \mathrm{H}+5 \mathrm{Hex}\end{array}$ & $\begin{array}{l}\text { B) } 3105.78 \\
\text { C) } 3429.46 \\
\text { C) } 3590.15\end{array}$ \\
\hline P4T & 127 & LNGK & 4 & 430.504 & & ND \\
\hline P5T & 138 & VLAAMYQGTIK & 11 & 1194.455 & $\mathrm{P} 5 \mathrm{~T}+6 \mathrm{Hex}$ & B) 2166.65 \\
\hline P6T & 164 & TWDDPQIAALNPGVNLPGTAVVPLHR & 26 & 2752.125 & & B) 2751.45 \\
\hline P7T & 180 & SDGSGDTFLFTQYLSK & 16 & 1765.894 & & C) 1765.82 \\
\hline P8T & 188 & QDPEGWGK & 8 & 915.958 & & ND \\
\hline P9T & 238 & $\begin{array}{l}\text { SPGFGTTVDFPAVPGALGENGNGGMVTGCAE } \\
\text { TPGCVAYIGISFLDQASQR }\end{array}$ & 50 & 4918.459 & & C) 4916.29 \\
\hline P10T & 270 & GLGEAQLGQSSGNFLLPDAQSIQAAAAGFASK & 32 & 3105.411 & & $\begin{array}{l}\text { B) } 3104.56 \\
\text { C) } 3105.89\end{array}$ \\
\hline P11T & 301 & TPANQAISMIDGPAPDGYPIINYEYAIVNNR & 31 & 3378.761 & & $\begin{array}{l}\text { B) } 3377.64 \\
\text { C) } 3379.80\end{array}$ \\
\hline P12T & 303 & QK & 2 & 274.320 & & ND \\
\hline Р13Т & 324 & DAATAQTLQAFLHWAITDGNK & 21 & 2272.502 & & $\begin{array}{l}\text { B) } 2272.13 \\
\text { C) } 2271.81\end{array}$ \\
\hline P14T & 342 & ASFLDQVHFQPLPPAVVK & 18 & 1993.336 & & $\begin{array}{l}\text { B) } 1993.08 \\
\text { C) } 1994.49\end{array}$ \\
\hline P15T & 353 & LSDALIATISS & 11 & 1090.239 & $\mathrm{P} 15 \mathrm{~T}+4 \mathrm{Hex}$ & B) 1738.59 \\
\hline
\end{tabular}

Mark of $B$ ) and $C$ ) referred the mass spectra from Fig. $4 \mathrm{~b}$ and c, respectively

Hex hexose, ND no determined, $T$ trypsin, $a a$ amino acids

Table 5 Theoretical and obtained peptides mass generated by Lys-C digestion of rPstS-1 produced in P. pastoris

\begin{tabular}{|c|c|c|c|c|c|c|}
\hline Peptide name & $\begin{array}{l}\text { Position } \\
\text { of cleavage } \\
\text { site }\end{array}$ & Peptide & Length (aa) & $\begin{array}{l}\text { Theoretical } \\
\text { Peptide mass } \\
\text { (Da) }\end{array}$ & Modification & Peptide mass (Da) \\
\hline P1 & 6 & AGCGSK & 6 & 521.589 & & ND \\
\hline P2 & 97 & $\begin{array}{l}\text { PPSGSPETGAGAGTVATTPASSPVTLAETGSTL } \\
\text { LYPLFNLWGPAFHERYPQVTITAQGTGSGAGIA } \\
\text { QAAAGTVNIGASDAYLSEGDMAAHK }\end{array}$ & 91 & 8916.801 & & ND \\
\hline P3 & 123 & GLMNIALAISAQQVNYNLPGVSEHLK & 26 & 2781.222 & & ND \\
\hline P4 & 127 & LNGK & 4 & 430.504 & & ND \\
\hline P5 & 138 & VLAAMYQGTIK & 11 & 1194.455 & & ND \\
\hline P6 & 180 & $\begin{array}{l}\text { TWDDPQIAALNPGVNLPGTAVVPLHRSDGSGD } \\
\text { TFLFTQYLSK }\end{array}$ & 42 & 4500.004 & & ND \\
\hline P7 & 188 & QDPEGWGK & 8 & 915.958 & & D) 916.41 \\
\hline P8 & 270 & $\begin{array}{l}\text { SPGFGTTVDFPAVPGALGENGNGGMVTGCAE } \\
\text { TPGCVAYIGISFLDQASQRGLGEAQLGQSSGN } \\
\text { FLLPDAQSIQAAAAGFASK }\end{array}$ & 82 & 8005.854 & & D) 8001.84 \\
\hline P9 & 303 & TPANQAISMIDGPAPDGYPIINYEYAIVNNRQK & 33 & 3635.065 & & D) 3633.80 \\
\hline P10 & 324 & DAATAQTLQAFLHWAITDGNK & 21 & 2272.502 & & D) 2272.13 \\
\hline P11 & 342 & ASFLDQVHFQPLPPAVVK & 18 & 1993.336 & & ND \\
\hline P12 & 353 & LSDALIATISS & 11 & 1090.239 & & ND \\
\hline
\end{tabular}

Mark of $D$ ) referred the mass spectrum from Fig. $4 \mathrm{~d}$

Hex hexose, $N D$ no determined 


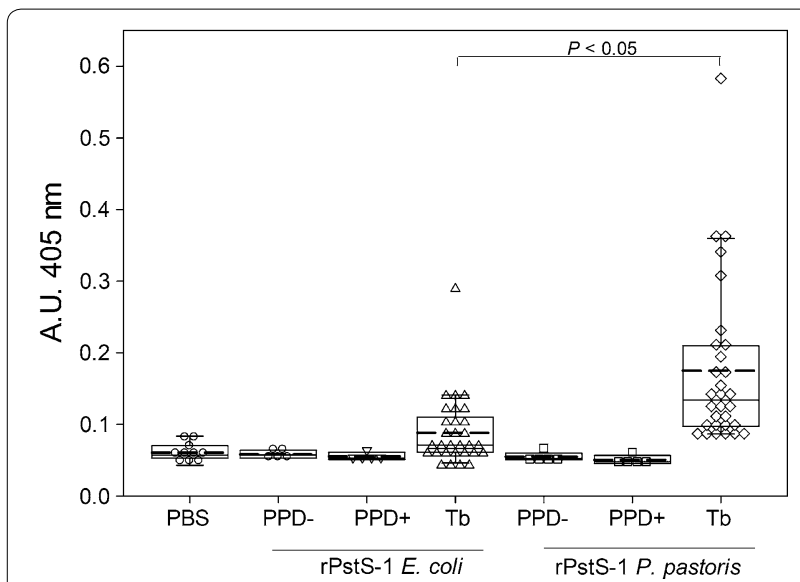

Fig. 6 Box plot analysis of antibody reactivity to recombinant antigens rPstS-1. Recombinant proteins (from E. coli and P. pastoris) were tested with PPD-negative $(n=5)$, PPD-positive sera $(n=5)$ at 1:100 and active-TB sera $(n=30)$ at 1:500 dilution. The reactivity is reported as difference of the absorbance units observed for the different group of sera by ELISA using a lgG2 conjugated with AP. Different sera of each group were tested by duplicate. Mean (dashed lane), median, 10th, 25th, 75th and 90th percentiles as vertical boxes with error bars are shown. Dunn's test ws used for all pairwise comparisons and comparisons against a control group (PBS) following rank-based ANOVA

was purchased from ThermoFisher Scientific. The HPLC grade reagents acetonitrile and trifluoroacetic acid were purchased from JT Baker (Phillipsburg, NJ, USA). Plasmid propagation and subcloning steps were carried out in One Shot ${ }^{\mathrm{TM}}$ TOP 10 chemically competent E. coli purchased from ThermoFisher Scientific and cultured in Luria-Bertani medium (Merck). The expression of rPstS-1 was carried out in Pichia pastoris X-33 using the $\mathrm{pPICZ} \alpha \mathrm{B}$ vector (ThermoFisher Scientific). E. coli Histagged-rPstS-1 was expressed as previously described [23].

\section{Vector construction: pPICZaB-PstS1}

The gene sequence encoding PstS1 (Rv0934) was obtained from GenBank ID No. 885724. This nucleotide sequence was then modified to create the preferential codon usage for $P$. pastoris [70, 71]. To avoid N-glycosylation, the asparagines at residues 57 and 247 were substituted with glutamines [79]. The optimized sequence was chemically synthesized and cloned into the pUC57 plasmid by GenScript (Piscataway, NJ. USA). The recombinant vector pPICZ $\alpha$ B-PstS-1 was obtained from ligation of the chemically synthesized gene, previously digested with PstI and $\mathrm{KpnI}$, to the pPICZ $\alpha \mathrm{B}$ vector using T4 DNA ligase. The fragment was inserted into $\mathrm{pPICZ} \alpha \mathrm{B}$ downstream of the $\alpha$-mating factor secretion signal and under the control of the AOX1 (alcohol oxidase 1) promoter. A stop codon
(TAA) was incorporated at the $3^{\prime}$ end of the sequence. The recombinant plasmid pPICZ $\alpha$ B-PstS-1 containing the coding sequence for the non-tagged PstS-1 was then propagated using One Shot ${ }^{\mathrm{TM}}$ TOP 10 chemically competent E. coli cultured in Luria-Bertani medium containing $25 \mu \mathrm{g} / \mathrm{mL}$ Zeocin $^{\mathrm{TM}}$. The plasmid was purified and the sequence of the insert determined. The resulting pPICZ $\alpha \mathrm{B}$-PstS- 1 plasmid was linearized and used to transform electro-competent $P$. pastoris $\mathrm{X}-33$ suspended in $1 \mathrm{M}$ sorbitol, at a setting of $1.5 \mathrm{kV}, 25 \mu \mathrm{F}$, and $186 \mathrm{ohms}$ for the BTX Electroporation System (Genetronics, San Diego, CA, USA). Transformed cells were selected using YPD agar (yeast extract $10 \mathrm{~g} / \mathrm{L}$, dextrose $20 \mathrm{~g} / \mathrm{L}$, peptone $20 \mathrm{~g} / \mathrm{L}, 1 \mathrm{M}$ sorbitol, and agar $20 \mathrm{~g} / \mathrm{L}$ ) supplemented with $\operatorname{Zeocin}^{\mathrm{TM}}(100 \mu \mathrm{g} / \mathrm{mL})$ at $30^{\circ} \mathrm{C}$. Positive clones were then stored in $1.0 \mathrm{~mL}$ cryovials at $-80^{\circ} \mathrm{C}$ in $20 \%$ glycerol. The clones producing the highest protein expression levels of rPstS-1 were selected using SDS-PAGE.

\section{Analytical methods}

Pichia pastoris growth was determined by measuring the $\mathrm{OD}_{600}$ (Spectronic Genesys 20, Thermo Fisher Scientific). Biomass was evaluated by measuring dry weight; $5 \mathrm{~mL}$ of culture was filtered through a $0.45 \mu \mathrm{m}$ pore size membrane (Merck-Millipore, Billerica, MA, USA), and washed once with one volume of distilled water. The biomass obtained was dried for $24 \mathrm{~h}$ in an oven at $65^{\circ} \mathrm{C}$, then placed for $1 \mathrm{~h}$ in a desiccator, and weighed thereafter. The supernatant was used to measure glycerol consumption using a colorimetric method previously described by Müller et al. [104]. Methanol consumption was determined using the Biochemistry Analyzer YSI 2900 (YSI Life Sciences, Yellow Springs, OH, USA).

\section{Production of $P$. pastoris rPstS- 1 in shaker flasks and bioreactors}

Baffled shake flasks (BSF, $250 \mathrm{~mL}$, Duran ${ }^{\circledR}$ Erlenmeyer flask, narrow neck, Borosilicate Glass, Mainz, Germany) containing $50 \mathrm{~mL}$ of BMGY media (yeast extract $10 \mathrm{~g} / \mathrm{L}$, peptone $20 \mathrm{~g} / \mathrm{L}$, glycerol $10 \mathrm{~mL} / \mathrm{L}$, and $100 \mathrm{mM}$ potassium phosphate, initial $\mathrm{pH}$ of 6.0) were inoculated with $200 \mu \mathrm{L}$ of culture from cryovials of the selected clone. After the glycerol was depleted, the cells were harvested by centrifugation at $6300 \times g$ for $15 \mathrm{~min}$ and the resulting pellet was resuspended in $50 \mathrm{~mL}$ of BMMY (yeast extract $10 \mathrm{~g} / \mathrm{L}$, peptone $20 \mathrm{~g} / \mathrm{L}$, methanol $10 \mathrm{~mL} / \mathrm{L}$, and $100 \mathrm{mM}$ potassium phosphate, $\mathrm{pH}$ 6.0). All cultures were incubated at $30^{\circ} \mathrm{C}$ in an orbital shaker at $250 \mathrm{rpm}$ (New Brunswick Scientific C251, Eppendorf Inc., Enfield, CT, USA).

For bioreactor experiments (containing 1.0 L of BMGY medium, Applikon Biotechnology, Netherlands), the medium was inoculated with BSF cultures at an initial $\mathrm{OD}_{600}$ of $0.5 \mathrm{AU}$. The BSF inoculum was derived by 
inoculating $50 \mathrm{~mL}$ of YPD with one vial of the selected clone and incubating at $30^{\circ} \mathrm{C}$ and $250 \mathrm{rpm}$ for $24 \mathrm{~h}$. Bioreactor cultures were carried out at $29{ }^{\circ} \mathrm{C}$, without $\mathrm{pH}$ control and the dissolved oxygen tension (DOT) was set at $35 \%$ (with respect to air saturation) and controlled by cascade, changing the agitation speed (between 200 and $1000 \mathrm{rpm})$, maintaining an airflow of $1.0 \mathrm{~L} / \mathrm{min}(1 \mathrm{vvm})$ using a proportional-integral-derivative (PID) control strategy [105]. DOT, temperature, agitation and $\mathrm{pH}$ values were acquired and controlled by the ADI-1010 and BioXper $t^{\circledR}$ software (Applikon Biotechnology). The total consumption of glycerol $(12.6 \mathrm{~g} / \mathrm{L})$ was assumed to have occurred when $95 \%$ of the DOT was reached, at which point the induction phase was started by the addition of methanol $(7.9 \mathrm{~g} / \mathrm{L})$. Each time the DOT reached above $80 \%$, the feeding of methanol $(7.9 \mathrm{~g} / \mathrm{L})$ was done. Samples were collected every $6 \mathrm{~h}(1.0 \mathrm{~mL})$, the supernatants were obtained by centrifugation at $8000 \times g$, and frozen for further analysis. All cultures were grown as three independent replicates and the results are expressed as the mean \pm standard deviation.

\section{Production of $E$. coli rPstS-1 in bioreactors}

The Escherichia coli (strain DE3) used to produce rPstS-1 was grown in a bioreactor (1.0 L Luria-Bertani culture medium, Applikon Biotechnology). The bioreactor cultures were carried out at $37^{\circ} \mathrm{C}$, without $\mathrm{pH}$ control, and the DOT was set at 35\% (with respect to air saturation) and controlled by cascade changing the agitation speed (between 200 and $1000 \mathrm{rpm}$ ), maintaining an airflow of $1.0 \mathrm{~L} / \mathrm{min}(1 \mathrm{vvm})$ using a proportionalintegral-derivative (PID) control strategy [105]. After $4 \mathrm{~h}$ of growth $\left(\mathrm{OD}_{600}\right.$ near 1.5 A.U.) the induction phase was started by the addition of $0.1 \mathrm{mM}$ of isopropyl- $\beta$ D-thiogalactopyranoside (IPTG). After $4 \mathrm{~h}$ of induction (O.D. 600 of $5.9 \mathrm{AU}$ ), the biomass was recovered by centrifugation. The cell suspension was sonicated in lysis buffer containing $0.5 \%(\mathrm{v} / \mathrm{v})$ Triton X-100 and the samples were centrifuged $(10,000 \times g$ for $10 \mathrm{~min})$. The recombinant PstS-1 was produced in inclusion bodies, which were solubilized using a denaturation buffer $(100 \mathrm{mM}$ $\mathrm{NaCl}, 50 \mathrm{mM}$ Tris-HCl, $6 \mathrm{M} \mathrm{GuHCl}, \mathrm{pH}$ 8).

\section{Total protein quantification, SDS-PAGE, and western blotting}

The concentration of total soluble proteins in the supernatants was determined using a Bradford protein assay (Bio-Rad Inc, Hercules, CA, USA) following the supplier's recommendations. Calibration curves were prepared using bovine serum albumin. Samples and standards were prepared as triplicates and absorbances measured at $595 \mathrm{~nm}$ using a plate reader (Stat Fax 4200, Awareness Technology, Palm City, FL, USA). Total protein from
$500 \mu \mathrm{L}$ of supernatant was precipitated with 1 volume of trichloroacetic acid (30\%) in cold acetone. Precipitation was carried out overnight at $-20{ }^{\circ} \mathrm{C}$ followed by centrifugation at $14,000 \times g$ for 25 min. Pellets were washed with acetone $(80 \%)$, dried at $60{ }^{\circ} \mathrm{C}$ for $5 \mathrm{~min}$, and then were suspended in $20 \mu \mathrm{L}$ of Milli-Q water. The precipitated samples were separated by electrophoresis on $12 \%$ SDS-PAGE gels [106]. Proteins were visualized by staining with Coomassie Brilliant Blue R-250 the stained gels imaged using Image-LabTM software and the Gel DocTM EZ System (Bio-Rad Inc, USA). A pre-stained protein ladder PageRuler $^{\mathrm{TM}}$ (Thermo Fisher Scientific, USA) was used to assess molecular mass.

To detect recombinant proteins by western blot, the proteins were separated by SDS-PAGE and then transferred to a polyvinylidene difluoride (PVDF) Immobilon- $\mathrm{P}^{\mathrm{TM}}$ membrane. The transblotted membranes were blocked with skimmed milk $(5 \%)$ in phosphate-buffered saline (PBS) containing Tween-20 (0.05\%). After three washes with PBS-Tween-20, the membranes were incubated with an anti-Mycobacterium tuberculosisPstS-1 polyclonal antibody (ArtNr: OACA02044. Aviva System Biology Co., San Diego, CA, USA; diluted to $1 / 2000$ ) for $1 \mathrm{~h}$ at room temperature. After incubation, the membranes were washed twice with PBS-Tween 20 and incubated with peroxidase conjugated anti-mouse immunoglobulin G antibodies diluted 1/2000, at room temperature for $30 \mathrm{~min}$. Membranes were again washed twice with PBS-Tween, and the immunoreactive bands revealed by chemiluminescence (Thermo Scientific, SuperSignal ${ }^{\circledR}$ West Pico Chemiluminescent Substrate). The bands were visualized using a C-digital scanner (LICOR, NE, USA).

For a comparative study of the ability of the antigens to be recognized by an antibody, western blot experiments were performed [64] using three different amounts $(2,1$, and $0.5 \mu \mathrm{g})$ of $\mathrm{rPstS}-1$ produced in either $P$. pastoris or $E$. coli. The membrane was incubated with a rabbit anti-Mycobacterium tuberculosis-PstS-1 polyclonal antibody (ArtNr: OACA02044. Aviva System Biology Co. USA; diluted 1/2000) for $1 \mathrm{~h}$ at room temperature, or with a human serum sample (diluted $1 / 300$ in TBS) from a patient with clinically confirmed active TB, and incubated overnight at $4{ }^{\circ} \mathrm{C}$. The bound antibodies were detected using HRP conjugated a goat anti-human IgG-Fc (Bethyl Laboratories, Inc., Montgomery, TX, USA, Cat. No. A80-104P-92) at 1/12,000 dilution in TBS for $2 \mathrm{~h}$ at room temperature. The purified rPstS-1 proteins from P. pastoris and E. coli were quantified using a Bradford protein assay (Bio-Rad, Richmond, CA, USA) following the supplier's recommendations. Immunoreactive bands were detected by chemiluminescence (Thermo Scientific, SuperSignal ${ }^{\circledR}$ 
West Pico Chemiluminescent Substrate), and band visualization was performed using a C-digital scanner (LICOR, NE, USA). Densitometric analysis was performed using Image Lab ${ }^{\mathrm{TM}}$ Software 6.0.1 (Bio-Rad).

\section{Purification of $\mathrm{rPstS}-1$}

After $73 \mathrm{~h}$ of cultivation of the recombinant $P$. pastoris in the presence of methanol in the bioreactor, biomass clarification was carried out by tangential filtration (Sartojet pump, loaned by Sartorius Stedim, Gotinga, Germany), using a membrane with a $100 \mathrm{kDa}$ cut off (Sartojet, Sartorius); phenylmethylsulfonyl fluoride (PMSF, Merck) was added to the filtrate to a final concentration of $0.1 \mathrm{mM}$. Following this, a membrane with a $10 \mathrm{kDa}$ cut-off was used to concentrate the previous filtrate. The retained fraction $(10-100 \mathrm{kDa})$ was concentrated by lyophilization of up to $90 \%$ of the initial volume, and then filtered using a $0.2 \mu \mathrm{m}$ polypropylene filter (Minisart Sryinge filter, Sartorius). Finally, rPstS-1 was purified by reverse phase high performance liquid chromatography (RPHPLC, Shimadzu, Kyoto, Japan). The samples were separated using a PROTO300 Semi-Prep C4 column $(10 \mu \mathrm{m}$, $250 \times 10 \mathrm{~mm}$ ) and XBridge Protein BEH C4 column (300 $\AA, 3.5 \mathrm{~mm}, 4.6 \mathrm{~mm} \times 150 \mathrm{~mm}$ ). The composition of the solvents used to equilibrate the columns was as follows: buffer A contained Milli Q water with $0.1 \%$ trifluoroacetic acid and buffer B contained acetonitrile with $0.1 \%$ trifluoroacetic acid. The recombinant protein was eluted with a gradient of acetonitrile. The separation started with $20 \%$ of buffer B solution for $5 \mathrm{~min}$, then a gradient of buffer B from $20 \%$ to $60 \%$ was applied for the next $20 \mathrm{~min}$. Elution was monitored by measuring the absorbances at 280 and $220 \mathrm{~nm}$. Purity was evaluated from the chromatogram obtained from each run by analyzing the representative area of each peak.

The purification of E. coli rPstS-1 was carried out by affinity chromatography of the His-tagged-rPstS-1 using an FPLC system (Econo System, Bio-Rad Richmond, CA, USA) using a Ni-NTA Agarose (Qiagen, Venlo, Netherlands). The rPstS-1 was eluted with $100 \mathrm{mM} \mathrm{NaCl}$, $50 \mathrm{mM}$ Tris- $\mathrm{HCl}, 8 \mathrm{M}$ urea, $250 \mathrm{mM}$ imidazole, $\mathrm{pH}$ 5.9. The rPstS- 1 was then further purified by reverse phase high performance liquid chromatography (RP-HPLC, Shimadzu, Kyoto, Japan), using a PROTO300 SemiPrep C4 column $(10 \mu \mathrm{m}, 250 \times 10 \mathrm{~mm})$ and the XBridge Protein BEH C4 column (300 A, $3.5 \mathrm{~mm}, 4.6 \mathrm{~mm} \mathrm{X}$ $150 \mathrm{~mm}$ ). The recombinant protein was eluted with a gradient of $0 \%$ to $60 \%$ of acetonitrile, using buffer A (Milli Q water containing $0.1 \%$ trifluoroacetic acid) and buffer $\mathrm{B}$ (acetonitrile containing $0.1 \%$ trifluoroacetic acid). Elution was monitored by measuring absorbances at 280 and $220 \mathrm{~nm}$.

\section{Circular dichroism spectroscopy}

The secondary structure of both forms of rPstS-1 (from $P$. pastoris and E. coli) were determined by far-UV circular dichroism (CD) spectroscopy using a Jasco J-715 spectropolarimeter (Jasco Inc., MD. USA). The CD spectra were obtained from samples dissolved in $50 \mathrm{mM}$ Tris, $100 \mathrm{mM} \mathrm{NaCl}, 12 \mathrm{mM} \mathrm{CaCl}_{2}$ at $\mathrm{pH} 8$, with protein concentrations of 125 and $250 \mu \mathrm{g} / \mathrm{mL}$. Spectra were recorded from 190 to $260 \mathrm{~nm}$ at a scan speed of $20 \mathrm{~nm} / \mathrm{min}$ and a response time of $1 \mathrm{~s}$, with each spectrum representing the sum of four accumulations. All spectra were acquired at $25{ }^{\circ} \mathrm{C}$ in a $1-\mathrm{mm}$ path length cell. The $\mathrm{CD}$ data were analyzed using the CAPITO CD Analysis \& Plotting Tool (http://capito.nmr.leibniz-fli.de/index.php) to provide estimates of the secondary structure content [93]. The mean residue ellipticity $\left([\Theta]\right.$ in $\left.\operatorname{grad} . \mathrm{cm}^{2} . \mathrm{dmol}^{-1}\right)$ was calculated in accordance with the equation [107]: $[\Theta]=\mathrm{MRW} \Theta / 10$ d.c where MRW is the mean residue weight, $\Theta$ is the observed ellipticity (millidegrees), $d$ is the pathlength $(\mathrm{cm})$, and $c$ is the concentration $(\mathrm{mg} / \mathrm{mL})$.

\section{Mass spectrometry analysis}

The molecular mass of $P$. pastoris rPstS- 1 was determined by MALDI-TOF, using a Bruker Microflex instrument equipped with a $20-\mathrm{Hz}$ nitrogen laser at $\mathrm{I}=337 \mathrm{~nm}$. Approximately 500 fmol of rPstS- 1 and $\alpha$-cyano-4hydroxycinnamic acid $(10 \mathrm{mg} / \mathrm{mL})$ solutions were mixed $(1: 1 \mathrm{v} / \mathrm{v})$ and spotted onto stainless steel plates. Samples were analyzed in the positive ion detection and linear mode; 70 laser shots were integrated into a single mass spectrum.

Sequence identification of the P. pastoris rPstS-1 purified by RP-HPLC was carried out as previously described [108]. Briefly, $50 \mu \mathrm{g}$ of rPstS-1 was reduced with $10 \mathrm{mM}$ DTT in $100 \mathrm{mM} \mathrm{NH} \mathrm{NCO}_{3}$ for $5 \mathrm{~min}$ at room temperature and then alkylated with $54 \mathrm{mM}$ iodoacetamide in $100 \mathrm{mM} \mathrm{NH}_{4} \mathrm{HCO}_{3}$ at room temperate for $15 \mathrm{~min}$ in dark. After reduction and alkylation, the protein was digested with trypsin (recombinant proteomics grade, Roche, Cat. No. 03708985001) dissolved in $100 \mathrm{mM}$ Tris, $\mathrm{pH} 8.5$ and $1 \mathrm{mM} \mathrm{CaCl}_{2}$, at a $1 / 50$ ratio of enzyme to protein weight. The enzymatic reaction was performed for $18 \mathrm{~h}$ at $37^{\circ} \mathrm{C}$. On the other hand, a second treated sample (reduced and alkylated) containing $50 \mu \mathrm{g}$ of purified protein was digested with the proteolytic enzyme Lys-C (Roche, Switzerland) in digestion buffer (25 mM Tris $\mathrm{HCl}, 1 \mathrm{mM}$ EDTA, $\mathrm{pH} 8.5$,) at a 1/100 ratio of enzyme to protein weight. The enzymatic reaction was performed for $16 \mathrm{~h}$ at $37^{\circ} \mathrm{C}$. Mass spectrometry analyses of the digested peptides were performed with $1 \mu \mathrm{L}$ of the enzymatic reaction mixed with $5 \mu \mathrm{L}$ of $30 \%$ acetonitrile $(\mathrm{ACN}), 70 \%$ water, $0.1 \%$ trifluoroacetic acid 
(TFA) saturated with $\alpha$-cyano-4-hydroxycinnamic acid. Following this, $1 \mu \mathrm{L}$ of this solution was analyzed in a matrix assisted laser desorption ionization time-of-flight analyzer (MALDI-TOF, Bruker Microflex) equipped with a $20-\mathrm{Hz}$ nitrogen laser at $\mathrm{I}=337 \mathrm{~nm}$. Spectra were recorded in the linear positive mode for the mass range 1000 to $13,000 \mathrm{Da}$.

The identification of the sequence of tryptic peptides was performed using a MALDI-TOF-TOF 4800 (Applied Biosystems, Foster City, CA, USA). MS/MS experiments were carried out at $1 \mathrm{kV}$ with collision-induced dissociation using air as the collision gas. Digested peptides were reconstituted in a solution of $\mathrm{H}_{2} \mathrm{O}$ :ACN:TFA (50:50:0.1) at nanomolar concentrations. In order to crystalize the peptides, $0.5 \mu \mathrm{L}$ of the sample was mixed with $1.0 \mu \mathrm{L}$ of the matrix $\alpha$-cyano-4-hydroxycinnamic acid as also with with $1.0 \mu \mathrm{L}$ of the matrices 3,5-dimethoxy-4-hydroxycinnamic acid and $\alpha$-cyano-4-hydroxycinnamic acid. Both preparations were done in micromolar concentrations and deposited on stainless steel plates at room temperature until complete evaporation and simultaneous crystal formation. To ionize samples, laser pulses using a nitrogen source and a $355 \mathrm{~nm}$ wavelength were used. The duration, intensity, and number of pulses were adjusted depending on the matrix used and the ease of ionization of the sample, which is directly related to the chemical structure of the molecules. The detected signals were stored and analyzed with the ProteinPilot 1.4 program coupled to the system.

\section{Sero-reactivity experiments by ELISA}

A 96-well microplate (Nunc-ImmunoPlate, Maxisorp Surface, Thermo Fisher) was coated with $100 \mu \mathrm{L} /$ well of the recombinant protein $(5 \mu \mathrm{g} / \mathrm{mL})$ in bicarbonate buffer solution (PBS) and incubated overnight at $4{ }^{\circ} \mathrm{C}$, then washed three times for 1 min each with PBS, blocked with $150 \mu \mathrm{L}$ of BSA $(0.25 \%)$ in PBS for $1.5 \mathrm{~h}$ at $37^{\circ} \mathrm{C}$, and then washed five times with PBS. Following this, $100 \mu \mathrm{L}$ of each serum, diluted in blocking solution (at two dilutions; $1: 100$ and 1:500), was added to the appropriate well and incubated for $1.5 \mathrm{~h}$ at $37^{\circ} \mathrm{C}$ and then washed three times with $250 \mu \mathrm{L}$ of Tween 20 (0.05\%) in PBS. The wells were then incubated with $100 \mu \mathrm{L}$ of secondary antibody mouse anti-human IgG2 (1:500 PBS/Tween 0.05\%) coupled to alkaline phosphatase (Thermo Fisher Scientific), for $1.5 \mathrm{~h}$ at $37^{\circ} \mathrm{C}$ in the dark and washed four times with $250 \mu \mathrm{L}$ of Tween $20(0.05 \%)$ in PBS. To measure the alkaline phosphatase activity, SIGMAFAST ${ }^{\mathrm{TM}}$ p-nitrophenyl phosphate tablets were used as a substrate (Merck, Billerica, MA, USA). The diluted substrate $(75 \mu \mathrm{L})$ was added to each well followed by incubation for $30 \mathrm{~min}$ in the dark at room temperature. After the incubation period, the absorbance was measured at $405 \mathrm{~nm}$ in a plate reader
(Synergy|HTX, Biotek, Winooski, VT, USA). Each serum analysis was performed in duplicate. The sera from TB patients $(n=30)$ were randomly selected from the National Institute of Respiratory Diseases (INER, Mexico City, Mexico). Active pulmonary TB in all patients was confirmed by a clinically positive sputum smear, microscopy, culture in medium Middlebrook 7H10, and identification by molecular methods and resistance to rifampicin using the GeneXpert test. All sera were collected before starting the antibiotic treatment, after the confirmation of the acute phase of the disease. Additionally, the sera from subjects with positive $(n=5)$ and negative $(n=5)$ PPD tests were selected from a screening to evaluate mycobacterial infections in people from the State of Mexico, Mexico. These subjects did not present any clinical evidence of active tuberculosis.

\section{Statistical analyses}

All the data for kinetic parameters are represented as the mean of triplicates \pm standard deviation. Statistical significance between groups in the antibody reactivity assay was determined using the mean of 30 sera from patients with active TB compared with PBS as the control, and positive and negative PPD groups $(\mathrm{n}=5$, each). Dunn's test was used for all pairwise comparisons and comparisons against a control group (PBS) following rank-based ANOVA, based in the treatment of unequal group sizes. Differences were considered statistically significant if the $\mathrm{P}<0.05$.

\section{Additional files}

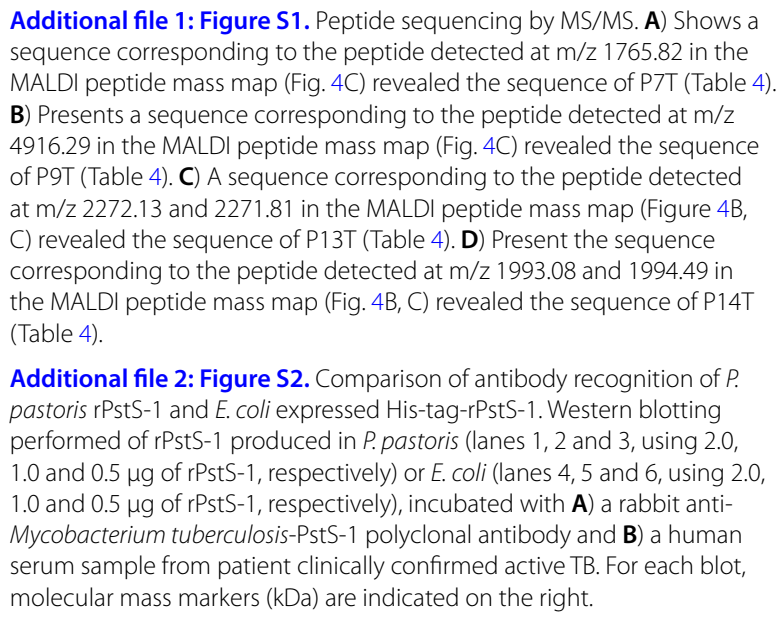

Additional file 1: Figure S1. Peptide sequencing by MS/MS. A) Shows a sequence corresponding to the peptide detected at $\mathrm{m} / \mathrm{z} 1765.82$ in the MALDI peptide mass map (Fig. 4C) revealed the sequence of P7T (Table 4). B) Presents a sequence corresponding to the peptide detected at $\mathrm{m} / \mathrm{z}$ 4916.29 in the MALDI peptide mass map (Fig. 4C) revealed the sequence of P9T (Table 4). C) A sequence corresponding to the peptide detected at $\mathrm{m} / \mathrm{z} 2272.13$ and 2271.81 in the MALDI peptide mass map (Figure 4B, C) revealed the sequence of $\mathrm{P} 13 \mathrm{~T}$ (Table 4). D) Present the sequence corresponding to the peptide detected at m/z 1993.08 and 1994.49 in the MALDI peptide mass map (Fig. 4B, C) revealed the sequence of P14T (Table 4).

Additional file 2: Figure S2. Comparison of antibody recognition of $P$. pastoris rPstS-1 and E. coli expressed His-tag-rPstS-1. Western blotting performed of rPstS-1 produced in P. pastoris (lanes 1, 2 and 3, using 2.0, 1.0 and $0.5 \mu \mathrm{g}$ of rPstS-1, respectively) or E. coli (lanes 4, 5 and 6, using 2.0, 1.0 and $0.5 \mu \mathrm{g}$ of rPstS-1, respectively), incubated with $\mathbf{A}$ ) a rabbit antiMycobacterium tuberculosis-PstS-1 polyclonal antibody and B) a human serum sample from patient clinically confirmed active TB. For each blot, molecular mass markers $(\mathrm{kDa})$ are indicated on the right.

\section{Authors' contributions}

GBC, DJL and NAVC performed the majority of the experiments. AIC, GBC and YLV executed the rPstS-1 sero-reactivity with human sera experiments. SARG, $D J L, G B C$ and NAVC performed the mass spectrometry runs and the analysis of the rPstS-1 antigens. DJL and NAVC designed and developed the clones 
used. CO contributed by supplying P. pastoris $X-33$, reagents, and the laccase protein. $C E$, provided the $E$. coli capable of producing the non-mannosylated rPstS-1, and the protocols required for its production. CO, AIC, YLV, MATR, NACV and RA, provided reagents and materials. GBC, DJL, AIC, YLV, SARG, RA, $\mathrm{CO}, \mathrm{MATR}$ and NAVC analyzed all the data and prepared the figures. GBC, DJL, MATR and NAVC prepared the manuscript. All authors read and approved the final manuscript.

\begin{abstract}
Author details
${ }^{1}$ Programa de Investigación de Producción de Biomoléculas, Departamento de Biología Molecular y Biotecnología, Instituto de Investigaciones Biomédicas, Universidad Nacional Autónoma de México, AP. 70228, CP. 04510 Ciudad de México, Mexico. ${ }^{2}$ Unidad de Proteómica, Instituto Nacional de Medicina Genómica (INMEGEN), Periférico Sur 4809, Col. Arenal Tepepan, Tlalpan, C.P. 14610 Ciudad de México, Mexico. ${ }^{3}$ Programa de Inmunología Molecular Microbiana, Departamento de Microbiología y Parasitología, Facultad de Medicina, Universidad Nacional Autónoma de México (UNAM), 04510 Ciudad de México, Mexico. ${ }^{4}$ Departamento de Ingeniería Celular y Biocatálisis, Instituto de Biotecnología UNAM, Av. Universidad 2001 Chamilpa, Cuernavaca, Morelos, Mexico. ${ }^{5}$ Departamento de Química de Biomacromoléculas, Instituto de Química, Universidad Nacional Autónoma de México, Av. Universidad 3000, Ciudad Universitaria, Apdo, Postal 70250, C.P. 04510 México City, Mexico. ${ }^{6}$ Departamento de Inmunología, Instituto de Investigaciones Biomédicas, Universidad Nacional Autónoma de México, Ciudad de México, Mexico. ${ }^{7}$ Programa de Investigación de Producción de Biomoléculas, Unidad de Bioprocesos, Departamento de Biología Molecular y Biotecnología, Instituto de Investigaciones Biomédicas, Universidad Nacional Autónoma de México, AP. 70228, CP. 04510 Ciudad de México, Mexico.
\end{abstract}

\section{Acknowledgements}

CGBC and DJL thank the scholarship from CONACYT-México (CGBC 366135: DJL 388590/288329). We also thank Eng. Abel Blancas-Cabrera, Biotech. Bach. Diego Rosiles, Biol. Lorena López-Griego, Dr. Angelica B. Vargas-Castillo, and M. Sc. Ramses Gamboa-Suasnavart for technical assistance in the cultures. We are also grateful to Sartorius Stedim for the loan of the Sartojet pump and technical support for the protein purification. We also thank "Unidad de Síntesis y Secuenciación" of the Biotechnology institute of UNAM (Instituto de Biotecnología of the Universidad Nacional Autónoma de México) for sequencing and primers synthesis. We are also grateful to Dr. Martha Torres Rojas, Subdirector de Investigación Biomédicas del Instituto Nacional de Enfermedades Resporatorias (INER, Mexico city, México) for sera collection. We also wish to thank Editage (http://www.editage.com) for English Language editing. This project was developed under the Institutional Program of the "Instituto de Investigaciones Biomédicas-UNAM": "La producción de biomoléculas de interés biomédico en bacterias y hongos".

\section{Competing interests}

The authors declare that they have no competing interests.

\section{Availability of data and materials}

All data generated or analyzed during this study are included in this published article and its additional files.

\section{Consent for publication}

Not applicable.

\section{Ethics approval and consent to participate} Not applicable.

\section{Funding}

This work was supported by Program for Research Projects and Technological Innovation, National Autonomous University of Mexico UNAM-PAPIIT (IN 208415; IN-209113). This work was partially funded by the National Council for Science and Technology (CONACYT, Consejo Nacional de Ciencia y Tecnología, 247473, 220795)

\section{Publisher's Note}

Springer Nature remains neutral with regard to jurisdictional claims in published maps and institutional affiliations.
Received: 4 September 2018 Accepted: 10 January 2019

Published online: 19 January 2019

\section{References}

1. WHO World Health Organization. 2017. Global tuberculosis report. http://www.who.int/tb/publications/global_report/en/. Accessed 15 Aug 2018.

2. Bahk YY, Kim SA, Kim JS, Euh HJ, Bai GH, Cho SN, Kim YS. Antigens secreted from Mycobacterium tuberculosis: identification by proteomics approach and test for diagnostic marker. Proteomics. 2004;11:3299307. https://doi.org/10.1002/pmic.200400980.

3. Bekmurzayeva A, Sypabekova M, Kanayeva D. Tuberculosis diagnosis using immunodominant, secreted antigens of Mycobacterium tuberculosis. Tuberculosis. 2013;4:381-8. https://doi.org/10.1016/j. tube.2013.03.003.

4. López-Vidal Y, de León-Rosales SP, Castañón-Arreola M, Rangel-Frausto MS, Meléndez-Herrada E, Sada-Díaz E. Response of IFN-gamma and IgG to ESAT-6 and $38 \mathrm{kDa}$ recombinant proteins and their peptides from Mycobacterium tuberculosis in tuberculosis patients and asymptomatic household contacts may indicate possible early-stage infection in the latter. Arch Med Res. 2004;35(4):308-17. https://doi.org/10.1016/j.arcme d.2004.04.008.

5. Polanco C, Castañón-González JA, Mancilla R, Buhse T, Samaniego JL, Gimbel A. Identification of proteins associated with Mycobacterium tuberculosis virulence pathway by their polar profile. Acta Biochim Pol. 2015;62(2):191-6. https://doi.org/10.18388/abp.2014_874.

6. Pukazhvanthen P, Anbarasu D, Basirudeen SA, Raja A, Singh M. Assessing humoral immune response of 4 recombinant antigens for serodiagnosis of tuberculosis. Tuberculosis. 2014;94(6):622-33. https:// doi.org/10.1016/j.tube.2014.09.006.

7. Serra-Vidal MM, Latorre I, Franken KL, Díaz J, de Souza-Galvão ML, Casas I, Maldonado J, Milà C, Solsona J, Jimenez-Fuentes MÁ, Altet N, Lacoma A, Ruiz-Manzano J, Ausina V, Prat C, Ottenhoff TH, Domínquez J. Immunogenicity of 60 novel latency-related antigens of Mycobacterium tuberculosis. Front Microbiol. 2014;5:517. https://doi.org/10.3389/fmicb .2014 .00517$.

8. Tiwari D, Tiwari RP, Chandra R, Bisen PS, Haque S. Efficient ELISA for diagnosis of active tuberculosis employing a cocktail of secretory proteins of Mycobacterium tuberculosis. Folia Biol. 2014;60(1):10-20.

9. Ihssen J, Kowarik M, Dilettoso S, Tanner C, Wacker M, Thöny-Meyer L. Production of glycoprotein vaccines in Escherichia coli. Microb Cell Fact. 2010;9:61. https://doi.org/10.1186/1475-2859-9-61.

10. Shi S, Yu L, Sun D, Liu J, Hickey AJ. Rational design of multiple TB antigens TB10.4 and TB10.4-Ag85B as subunit vaccine candidates against Mycobacterium tuberculosis. Pharm Res. 2009;27:224-34. https://doi. org/10.1007/s11095-009-9995-y.

11. Zhu X, Venkataprasad N, Thangaraj HS, Hill M, Singh M, Ivanyi J, Vordermeier HM. Functions and specificity of T cells following nucleic acid vaccination of mice against Mycobacterium tuberculosis infection. J Immunol. 1997;158(12):5921-6.

12. Uma Devi KR, Ramalingam B, Brennan PJ, Narayanan PR, Raja A. Specific and early detection of $\operatorname{lgG}, \lg A$ and $\lg M$ antibodies to Mycobacterium tuberculosis $38 \mathrm{kDa}$ antigen in pulmonary tuberculosis. Tuberculosis. 2001;81:249-53. https://doi.org/10.1054/tube.2001.0293.

13. Mustafa AS. Biotechnology in the development of new vaccines and diagnostic reagents against tuberculosis. Curr Pharmaceut Biotechnol. 2001;2:157-73.

14. Olsen AW, van Pinxteren LA, Okkels LM, Rasmussen PB, Andersen P. Protection of mice with a tuberculosis subunit vaccine based on a fusion protein of antigen 85B and ESAT-6. Infect Immun. 2001;69(5):2773-8. https://doi.org/10.1128/IAl.69.5.2773-2778.2001.

15. Ottenhoff TH, Kaufmann SH. Vaccines against tuberculosis: where are we and where do we need to go? PLoS Pathog. 2012;8(5):e1002607. https://doi.org/10.1371/journal.ppat.1002607.

16. Flores LL, Steingart KR, Dendukuri N, Schiller I, Minion J, Pai M, Ramsay A, Henry M, Laal S. Systematic review and meta-analysis of antigen detection tests for the diagnosis of tuberculosis. Clin Vaccine Immunol. 2011;18:1616-27. https://doi.org/10.1128/CVI.05205-11. 
17. Kunnath-Velayudhan S, Salamon H, Wang HY, Davidow AL, Molina DM, Huynh VT, Cirillo DM, Michel G, Talbot EA, Perkins MD, Felgner PL, Liang $X$, Gennaro ML. Dynamic antibody responses to the Mycobacterium tuberculosis proteome. Proc Natl Acad Sci USA. 2010;107(33):14703-8. https://doi.org/10.1073/pnas.1009080107.

18. WHO: An International roadmap for tuberculosis research. Geneva: WHO; 2011. http://www.stoptb.org/assets/documents/resources/publi cations/technical/tbresearchroadmap.pdf. Accessed 16 Aug 2018.

19. Mori T, Sakatani M, Yamagishi F, Takashima T, Kawabe Y, Nagao K, Shigeto E, Harada N, Mitarai S, Okada M, Suzuki K, Inoue Y, Tsuyuguchi K, Sasaki Y, Mazurek GH, Tsuyuguchi I. Specific detection of tuberculosis infection: an interferon- $\gamma$-based assay using new antigens. Am J Respir Crit Care Med. 2004;170(1):59-64. https://doi.org/10.1164/rccm.20040 2-1790C.

20. Mazurek GH. Division of tuberculosis elimination, national center for HIV, STD, and TB prevention, centers for disease control and prevention (CDC) Guidelines for using the QuantiFERON-TB Gold test for detecting Mycobacterium tuberculosis infection, United States. MMWR Recomm Rep. 2005;54:49-55.

21. Dorman SE, Belknap R, Graviss EA, Reves R, Schluger N, Weinfurter $P$ Wang Y, Cronin W, Hirsch-Moverman Y, Teeter LD, Parker M, Garrett DO, Daley $C L$, Tuberculosis Epidemiologic Studies Consortium. Interferon- $\gamma$ release assays and tuberculin skin testing for diagnosis of latent tuberculosis infection in healthcare workers in the United States. Am J Respir Crit Care Med. 2014;189(1):77-87. https://doi.org/10.1164/rccm.20130 2-0365oc.

22. Ragas A, Roussel L, Puzo G, Rivière $M$. The $M$. tuberculosis cell surface glycoprotein Apa as a potential adhesin to colonize the target cells via the innate immune system pulmonary C-type lectin SP-A. J Biol Chem. 2007;282(8):5133-42. https://doi.org/10.1074/jbc.m610183200.

23. González-Zamorano M, Mendoza-Hernández G, Xolalpa W, Parada C, Vallecillo AJ, Bigi F, Espitia C. Mycobacterium tuberculosis glycoproteomics based on ConA-lectin affinity capture of mannosylated proteins. J Proteome Res. 2009;8(2):721-33. https://doi.org/10.1021/pr800756a.

24. Nandakumar S, Kannanganat S, Dobos KM, Lucas M, Spencer JS, Fang S, McDonald MA, Pohl J, Birkness K, Chamcha V, Ramirez MV, Plikaytis BB, Posey JE, Amara RR, Sable SB. O-mannosylation of the Mycobacterium tuberculosis adhesin Apa is crucial for T cell antigenicity during infection but is expendable for protection. PLoS Pathog. 2013;9(10):e1003705. https://doi.org/10.1371/journal.ppat.1003705.

25. Smith GT, Sweredoski MJ, Hess S. O-linked glycosylation sites profiling in Mycobacterium tuberculosis culture filtrate proteins. J Proteomics. 2014;97:296-306. https://doi.org/10.1016/j.jprot.2013.05.011.

26. Villeneuve C, Etienne G, Abadie V, Montrozier H, Bordier C, Laval F, Daffe M, Maridonneau-Parini I, Astarie-Dequeker C. Surfaceexposed glycopeptidolipids of Mycobacterium smegmatis specifically inhibit the phagocytosis of mycobacteria by human macrophages. Identification of a novel family of glycopeptidolipids. J Biol Chem. 2003;278(51):51291-300. https://doi.org/10.1074/jbc.m306554200.

27. Liu CF, Tonini L, Malaga W, Beau M, Stella A, Bouyssié D, Jackson MC, Nigou J, Puzo G, Guilhot C, Burlet-Schiltz O, Rivière M. Bacterial proteinO-mannosylating enzyme is crucial for virulence of Mycobacterium tuberculosis. Proc Natl Acad Sci USA. 2013;110(16):6560-5. https://doi. org/10.1073/pnas.1219704110.

28. Romain F, Horn C, Pescher P, Namane A, Riviere M, Puzo G, Barzu O, Marchal G. Deglycosylation of the 45/47-kilodalton antigen complex of Mycobacterium tuberculosis decreases its capacity to elicit in vivo or in vitro cellular immune responses. Infect Immun. 1999;67(11):5567-72.

29. Horn C, Namane A, Pescher P, Rivière M, Romain F, Puzo G, Bârzu O, Marchal G. Decreased capacity of recombinant 45/47-kDa molecules (Apa) of Mycobacterium tuberculosis to stimulate T lymphocyte responses related to changes in their mannosylation pattern. J Biol Chem. 1999;274(45):32023-30. https://doi.org/10.1074/jbc.274.45.32023.

30. Lara M, Servín-González L, Singh M, Moreno C, Cohen I, Nimtz M, Espitia C. Expression, secretion, and glycosylation of the 45-and 47-kDa glycoprotein of Mycobacterium tuberculosis in Streptomyces lividans. App Environ Microbiol. 2004;70(2):679-85. https://doi.org/10.1128/ AEM.70.2.679-685.2004.

31. Kumar P, Amara RR, Challu VK, Chadda VK, Satchidanandam V. The Apa protein of Mycobacterium tuberculosis stimulates gamma interferon-secreting CD4+ and CD8+ T cells from purified protein derivative-positive individuals and affords protection in a guinea pig model. Infect Immun. 2003;71(4):1929-37. https://doi.org/10.1128/ |Al.71.4.1929-1937.2003.

32. Malen H, Berven FS, Fladmark KE, Wiker HG. Comprehensive analysis of exported proteins from Mycobacterium tuberculosis H37Rv. Proteomics. 2007;7(10):1702-18. https://doi.org/10.1002/pmic.200600853.

33. van Els CA, Corbière V, Smits K, van Gaans-van den Brink J, Poelen M, Mascart F, Meiring HD, Locht C. Toward understanding the essence of post-translational modifications for the Mycobacterium tuberculosis immunoproteome. Front Immunol. 2014;5:361. https://doi.org/10.3389/ fimmu.2014.00361.

34. Tailleux L, Schwartz O, Herrmann JL, Pivert E, Jackson M, Amara A, Legres L, Dreher D, Nicod LP, Gluckman JC, Lagrange PH, Gicquel B, Neyrolles O. DC-SIGN is the major Mycobacterium tuberculosis receptor on human dendritic cells. J Exp Med. 2003;197(1):121-7. https://doi. org/10.1084/jem.20021468.

35. Sanchez A, Espinosa P, Esparza MA, Colon M, Bernal G, Mancilla R. Mycobacterium tuberculosis 38-kDa lipoprotein is apoptogenic for human monocyte-derived macrophages. Scand J Immunol. 2009;69:20-8. https://doi.org/10.1111/j.1365-3083.2008.02193.x.

36. Esparza M, Palomares B, García T, Espinosa P, Zenteno E, Mancilla R. PstS1, the 38-kDa Mycobacterium tuberculosis glycoprotein is an adhesin, which binds the macrophage mannose receptor and promotes phagocytosis. Scand J Immunol. 2015;81(1):46-55. https://doi.org/10.1111/ sji.12249.

37. Andersen $A B$, Hansen EB. Structure and mapping of antigenic domains of protein antigen b, a 38,000-molecular-weight protein of Mycobacterium tuberculosis. Infect Immun. 1989;57(8):2481-8.

38. Harboe M, Wiker HG. The 38-kDa protein of Mycobacterium tuberculosis: a review. J Infect Dis. 1992;166(4):874-84.

39. Vordermeier HM, Harris DP, Moreno C, Singh M, Ivanyi J. The nature of the immunogen determines the specificity of antibodies and $T$ cells to selected peptides of the $38 \mathrm{kDa}$ mycobacterial antigen. Int Immunol. 1995;7(4):559-66

40. Andersen $A B$, Ljungqvist $L$, Olsen M. Evidence that protein antigen $b$ of Mycobacterium tuberculosis is involved in phosphate metabolism. Microbiology. 1990;136(3):477-80.

41. Espitia C, Elinos M, Hernandez-Pando R, Mancilla R. Phosphate starvation enhances expression of the immunodominant 38-kilodalton protein antigen of Mycobacterium tuberculosis: demonstration by immunogold electron microscopy. Infect Immun. 1992;60:2998-3001.

42. Andersen P. Effective vaccination of mice against Mycobacterium tuberculosis infection with a soluble mixture of secreted mycobacterial proteins. Infect Immun. 1994;62(6):2536-44.

43. Harboe M. The significance of proteins actively secreted by Mycobacterium tuberculosis in relation to immunity and complications of mycobacterial diseases. Int J Lepr Other Mycobact Dis. 1992;60(3):470-6.

44. Fonseca DP, Benaissa-Trouw B, van Engelen M, Kraaijeveld CA, Snippe $\mathrm{H}$, Verheul AF. Induction of cell-mediated immunity against Mycobacterium tuberculosis using DNA vaccines encoding cytotoxic and helper T-cell epitopes of the 38-kilodalton protein. Infect Immun. 2001;69(8):4839-45. https://doi.org/10.1128/IAl.69.8.4839-4845.2001.

45. Bothamley GH, Beck JS, Potts RC, Grange JM, Kardjito T, Ivanyi J. Specificity of antibodies and tuberculin response after occupational exposure to tuberculosis. J Infect Dis. 1992;166(1):182-6.

46. Silva VM, Kanaujia G, Gennaro ML, Menzies D. Factors associated with humoral response to Rv3875, $38 \mathrm{kDa}$ and $14 \mathrm{kDa}$ in patients with a spectrum of tuberculosis. Int J Tuberc Lung Dis. 2003;7(5):478-84.

47. Herrmann JL, Delahay R, Gallagher A, Robertson B, Young D. Analysis of post-translational modification of mycobacterial proteins using a cassette expression system. FEBS Lett. 2000;473(3):358-62. https://doi. org/10.1016/S0014-5793(00)01553-2.

48. Lengeler KB, Tielker D, Ernst JF. Protein-O-mannosyltransferases in virulence and development. Cell Mol Life Sci. 2008;65(4):528. https:// doi.org/10.1007/s00018-007-7409-z.

49. Proszynski TJ, Simons K, Bagnat M. O-glycosylation as a sorting determinant for cell surface delivery in yeast. Mol Biol Cell. 2004;15(4):1533-43. https://doi.org/10.1091/mbc.e03-07-0511.

50. Willer T, Valero MC, Tanner W, Cruces J, Strahl S. O-mannosyl glycans: from yeast to novel associations with human disease. Curr Opin Struct Biol. 2003;13(5):621-30. https://doi.org/10.1016/j.sbi.2003.09.003. 
51. Garfoot AL, Goughenour KD, Wüthrich M, Rajaram MV, Schlesinger LS, Klein BS, Rappleye CA. O-mannosylation of proteins enables histoplasma yeast survival at mammalian body temperatures. mBio. 2018;9(1):e02121-217. https://doi.org/10.1128/mbio.02121-17.

52. Lussier M, Sdicu AM, Bussereau F, Jacquet M, Bussey $H$. The Ktr1 $p_{\text {, }}$ $\mathrm{Ktr} 3 \mathrm{p}$, and Kre2p/Mnt1p mannosyltransferases participate in the elaboration of yeast $\mathrm{O}$ - and $\mathrm{N}$ - linked carbohydrate chains. J Biol Chem. 1997;272(24):15527-31. https://doi.org/10.1074/jbc.272.24.15527.

53. Gentzsch M, Tanner W. Protein-O-glycosylation in yeast: protein-specific mannosyltransferases. Glycobiology. 1997;7:481-6.

54. Braakman I, Hebert DN. Protein folding in the endoplasmic reticulum. Cold Spring Harb Perspect Biol. 2013;5:a013201.

55. Dobos K, Khoo K, Swiderek K, Brennan P, Belisle J. Definition of the full extent of glycosylation of the 45-Kilodalton glycoprotein of Mycobacterium tuberculosis. J Bacteriol. 1996;178(9):2498-506.

56. Duman JG, Miele RG, Liang H, Grella DK, Sim KL, Castellino FJ, Bretthauer RK. O-Mannosylation of Pichia pastoris cellular and recombinant proteins. Biotechnol Appl Biochem. 1998;28(Pt 1):39-45.

57. Akasaka-Manya K, Manya H, Hayashi M, Endo T. Different roles of the two components of human protein O-mannosyltransferase, POMT1 and POMT2. Biochem Biophys Res Commun. 2011;411(4):721-5. https ://doi.org/10.1016/j.bbrc.2011.07.012.

58. Ahmad M, Hirz M, Pichler H, Schwab H. Protein expression in Pichia pastoris: recent achievements and perspectives for heterologous protein production Appl Microbiol Biotechnol. 2014;98(12):5301-17. https:// doi.org/10.1007/s00253-014-5732-5.

59. Trimble RB, Lubowski C, Hauer CR 3rd, Stack R, McNaughton L, Gemmill TR, Kumar SA. Characterization of $\mathrm{N}$ - and $\mathrm{O}$ linked glycosylation of recombinant human bile salt-stimulated lipase secreted by Pichia pastoris. Glycobiology. 2004;14:265-74.

60. Häusler A, Ballou L, Ballou CE, Robbins PW. Yeast glycoprotein biosynthesis: MNT1 encodes an a-1,2-mannosyltransferase involved in O-glycosylation. Proc Natl Acad Sci USA. 1992;89:6846-50.

61. Yamada T, Uyeda A, Otsu M, Matsushima M, Sekiguchi K, Kikuchi M. Site-specific O-glycosylation of cell adhesive lysozyme in yeast. Biochemistry. 1994;33(13):3885-9.

62. Romero PA, Lussier M, Veronneau S, Sdicu AM, Herscovics A, Bussey H. Mnt2p and Mnt3p of Saccharomyces cerevisiae are members of the Mnn1p family of a-1,3-mannosyltransferases responsible for adding the terminal mannose residues of O-linked oligosaccharides. Glycobiology. 1999;9(10):1045-51.

63. VanderVen BC, Harder JD, Crick DC, Belisle JT. Export-mediated assembly of mycobacterial glycoproteins parallels eukaryotic pathways. Science. 2005;309(5736):941-3. https://doi.org/10.1126/science.11143 47.

64. Benabdesselem C, Fathallah DM, Huard RC, Zhu H, Jarboui MA, Dellagi K, Ho JL, Barbouche R. Enhanced patient serum immunoreactivity to recombinant Mycobacterium tuberculosis CFP32 produced in the yeast Pichia pastoris compared to Escherichia coli and its potential for serodiagnosis of tuberculosis. J Clin Microbiol. 2006;44(9):3086-93. https://doi. org/10.1128/JCM.02672-05.

65. Benabdesselem C, Barbouche MR, Jarboui MA, Dellagi K, Ho JL, Fathallah DM. High level expression of recombinant Mycobacterium tuberculosis culture filtrate protein CFP32 in Pichia pastoris. Mol Biotechnol. 2007;35(1):41-9.

66. Cereghino JL, Cregg JM. Heterologous protein expression in the methylotrophic yeast Pichia pastoris. FEMS Microbiol Rev. 2000;24(1):45-66. https://doi.org/10.1111/j.1574-6976.2000.tb00532.x.

67. Damasceno LM, Huang CJ, Batt CA. Protein secretion in Pichia pastoris and advances in protein production. Appl Microbiol Biotechnol. 2012;93(1):31-9. https://doi.org/10.1007/s00253-011-3654-z.

68. Gellissen G, Kunze G, Gaillardin C, Cregg JM, Berardi E, Veenhuis M, van der Klei I. New yeast expression platforms based on methylotrophic Hansenula polymorpha and Pichia pastoris and on dimorphic Arxula adeninivorans and Yarrowia lipolytica - a comparison. FEMS Yeast Res. 2005:5(11):1079-96. https://doi.org/10.1016/j.femsyr.2005.06.004

69. Walsh G. Biopharmaceutical benchmarks 2014. Nat Biotechnol. 2014;32(10):992-1000. https://doi.org/10.1038/nbt.3040.

70. De Schutter K, Lin YC, Tiels P, Van Hecke A, Glinka S, Weber-Lehmann J, Ruzé P, Van de Peer Y, Callewaert N. Genome sequence of the recombinant protein production host Pichia pastoris. Nat Biotechnol. 2009;27(6):561-6. https://doi.org/10.1038/nbt.1544.

71. Bai J, Swartz D, Protasevich I, Brouillette C, Harrell P, Hildebrandt E, Gasser B, Mattanovich D, Ward A, Chang G, Urbatsch I. A gene optimization strategy that enhances production of fully functional P-glycoprotein in Pichia pastoris. PLoS ONE. 2011;6(8):e22577. https://doi.org/10.1371/ journal.pone.0022577.

72. Yadava A, Ockenhouse F. Effect of codon optimization on expression levels of a functionally folded malaria vaccine candidate in prokaryotic and eukaryotic expression systems. Infect Immun. 2003;71(9):4961-9. https://doi.org/10.1128/IAI.71.9.4961-4969.2003.

73. Tsujikawa M, Okabayashi K, Morita M, Tanabe T. Secretion of a variant of human single-chain urokinase-type plasminogen activator without an $\mathrm{N}$-glycosylation site in the methylotrophic yeast Pichia pastoris and characterization of the secreted product. Yeast. 1996;12:541-53.

74. Hartner FS, Glieder A. Regulation of methanol utilization pathway genes in yeasts. Microb Cell Fact. 2006;5:39. https://doi. org/10.1186/1475-2859-5-39.

75. Inan M, Meagher MM. Non-repressing carbon sources for alcohol oxidase (AOX1) promoter of Pichia pastoris. J Biosci Bioeng. 2001;92(6):5859. https://doi.org/10.1016/S1389-1723(01)80321-2.

76. Ohi H, Miura M, Hiramatsu R, Ohmura T. The positive and negative cis-acting elements for methanol regulation in the Pichia pastoris AOX2 gene. Mol Gen Genet. 1994;243(5):489-99.

77. Wu J, Filutowicz M. Hexahistidine (His6)-tag dependent protein dimerization: a cautionary tale. Acta Biochim Pol. 1999;46(3):591-9.

78. Sainsbury F, Philippe VJ, Vorster J, Goulet MC, Michaud D. A chimeric affinity tag for efficient expression and chromatographic purification of heterologous proteins from plants. Front Plant Sci. 2016;15(7):141. https ://doi.org/10.3389/fpls.2016.00141.

79. Halliwell CM, Morgan G, Ou CP, Cass AE. Introduction of a (poly)histidine tag in L-lactate dehydrogenase produces a mixture of active and inactive molecules. Anal Biochem. 2001;295(2):257-61.

80. Fonda I, Kenig M, Gaberc-Porekar V, Pristovaek P, Menart V. Attachment of histidine tags to recombinant tumor necrosis factor-alpha drastically changes its properties. Sci World J. 2002;15(2):1312-25. https://doi. org/10.1100/tsw.2002.215.

81. Hong F, Meinander NQ, Jönsson LJ. Fermentation strategies for improved heterologous expression of laccase in Pichia pastoris. Biotechnol Bioeng. 2002;79(4):438-49. https://doi.org/10.1002/bit.10297.

82. Hazeu W, Donker RA. A continuous culture study of methanol and formate utilization by the yeast Pichia pastoris. Biotechnol Lett. 1983;5:399-404

83. Swartz JR, Cooney CL. Methanol inhibition in continuous culture of Hansenula polymorpha. Appl Environ Microb. 1981;41(5):1206-13.

84. Looser V, Lüthy D, Straumann M, Hecht K, Melzoch K, Kovar K. Effects of glycerol supply and specific growth rate on methanol-free production of CALB by P. pastoris: functional characterisation of a novel promoter. Appl Microbiol Biotechnol. 2017;101(8):3163-76. https://doi. org/10.1007/s00253-017-8123-x.

85. Paulová L, Hyka P, Branská B, Melzoch K, Kovar K. Use of a mixture of glucose and methanol as substrates for the production of recombinant trypsinogen in continuous cultures with Pichia pastoris Mut+. J Biotechnol. 2012;157(1):180-8. https://doi.org/10.1016/j.jbiot ec.2011.10.010.

86. Woo JH, Liu YY, Neville DM Jr. Minimization of aggregation of secreted bivalent anti-human T cell immunotoxin in Pichia pastoris bioreactor culture by optimizing culture conditions for protein secretion. J Biotechnol. 2006;121(1):75-85.

87. Baumann K, Maurer M, Dragosits M, Cos O, Ferrer P, Mattanovich D. Hypoxic fed-batch cultivation of Pichia pastoris increases specific and volumetric productivity of recombinant proteins. Biotechnol Bioeng. 2008;100:177-83. https://doi.org/10.1002/bit.21763.

88. Çalik P, Inankur B, Soyaslan E, Şahin M, Taşpinar H, AÇik E, Bayraktar E. Fermentation and oxygen transfer characteristics in recombinant human growth hormone production by Pichia pastoris in sorbitol batch and methanol fed-batch operation. J Chem Technol Biotechnol. 2010;85:226-33. https://doi.org/10.1002/jctb.2292.

89. Chiruvolu V, Eskridge K, Cregg J, Meagher M. Effects of glycerol concentration and $\mathrm{pH}$ on growth of recombinant Pichia pastoris yeast. Appl 
Biochem Biotechnol. 1998;75:163-73. https://doi.org/10.1007/BF027 87771.

90. Lopes M, Oliveira C, Domingues L, Mota M, Belo I. Enhanced heterologous protein production in Pichia pastoris under increased air pressure. Biotechnol Prog. 2014;30:1040-7. https://doi.org/10.1002/btpr.1964.

91. Singh M, Andersen AB, McCarthy JE, Rohde M, Schütte H, Sanders E, Timmis KN. The Mycobacterium tuberculosis 38-kDa antigen: overproduction in Escherichia coli, purification and characterization. Gene. 1992:117(1):53-60.

92. Khurshid S, Khalid R, Afzal M, Akhtar MW. Truncation of PstS1 antigen of Mycobacterium tuberculosis improves diagnostic efficiency. Tuberculosis. 2013;93(6):654-9. https://doi.org/10.1016/j.tube.2013.07.005

93. Wiedemann C, Bellstedt P, Görlach M. CAPITO—a web server-based analysis and plotting tool for circular dichroism data. Bioinformatics. 2013;29(14):1750-7.

94. Vyas NK, Vyas MN, Quiocho FA. Crystal structure of M. tuberculosis ABC phosphate transport receptor: specificity and charge compensation dominated by ion-dipole interactions. Structure. 2003;11(7):765-74. https://doi.org/10.1016/s0969-2126(03)00109-6.

95. Chauhan JS, Bhat AH, Raghava GPS, Rao A. GlycoPP: a webserver for prediction of $\mathrm{N}$ - and $\mathrm{O}$-glycosites in prokaryotic protein sequences. PLOS ONE. 2012;7(7):e40155. https://doi.org/10.1371/journ al.pone.0040155.

96. Neubert P, Halim A, Zauser M, Essig A, Joshi HJ, Zatorska E, Larsen ISB, Castells-Ballester J, Aebi M, Clausen H, Strahl S. Mapping the O-mannose glycoproteome in Saccharomyces cerevisiae. Mol Cell Proteomics. 2016;15(4):1323-37. https://doi.org/10.1074/mcp.M115.057505.

97. Nett JH, Cook WJ, Chen MT, Davidson RC, Bobrowicz P, Kett W, Brevnova E, Potgieter TI, Mellon MT, Prinz B, Choi BK, Zha D, Burnina I, Bukowski JT, Du M, Wildt S, Hamilton SR. Characterization of the Pichia pastoris protein-O-mannosyltransferase gene family. PLoS ONE. 2013;8(7):e68325. https://doi.org/10.1371/journal.pone.0068325.

98. Sousa AO, Henry S, Marója FM, Lee FK, Brum L, Singh M, Lagrange $\mathrm{PH}$, Aucouturier P. IgG subclass distribution of antibody responses to protein and polysaccharide mycobacterial antigens in leprosy and tuberculosis patients. Clin Exp Immunol. 1998;111(1):48-55. https://doi. org/10.1046/j.1365-2249.1998.00452.x.

99. Vidarsson $G$, Dekkers $G$, Rispens T. IgG subclasses and allotypes: from structure to effector functions. Front Immunol. 2014;5:520. https://doi. org/10.3389/fimmu.2014.00520.
100. Wilkinson RJ, Haslov K, Rappuoli R, Giovannoni F, Narayanan PR, Desai CR, Vordermeier HM, Paulsen J, Pasvol G, Ivanyi J, Singh M. Evaluation of the recombinant 38-kilodalton antigen of Mycobacterium tuberculosis as a potential immunodiagnostic reagent. J Clin Microbiol. 1997;35:553-7.

101. Wu X, Yang Y, Zhang J, Li B, Liang Y, Zhang C, Dong M, Cheng H, He J. Humoral immune responses against the Mycobacterium tuberculosis 38-Kilodalton, MTB48, and CFP-10/ESAT-6 antigens in tuberculosis. Clin Vaccine Immunol. 2010;17:372e5. https://doi.org/10.1128/cvi.00287-09.

102. Davidow A, Kanaujia GV, Shi L, Kaviar J, Guo X, Sung N, Kaplan G, Menzies D, Gennaro ML. Antibody profiles characteristic of Mycobacterium tuberculosis infection state. Infect Immun. 2005;73(10):6846-51. https:// doi.org/10.1128/IAl.73.10.6846-6851.2005.

103. Araujo LS, Mello FC, Silva Nde B, Leung JA, Machado SM, Sardella IG, Maciel Rde M, Saad MH. Evaluation of gamma interferon immune response elicited by the newly constructed PstS-1 (285-374): CFP10 fusion protein to detect Mycobacterium tuberculosis infection. Clin Vaccine Immunol. 2014;21(4):552-60. https://doi.org/10.1128/CVI.00726 $-13$.

104. Müller H, Salzig D, Czermak P. A rapid method for an offline glycerol determination during microbial fermentation. Electron J Biotechnol. 2015;18(3):252-5. https://doi.org/10.1016/j.ejbt.2015.01.005.

105. Trujillo-Roldán MA, Peña C, Ramírez OT, Galindo E. Effect of oscillating dissolved oxygen tension on the production of alginate by Azotobacter vinelandii. Biotechnol Prog. 2001;17(6):1042-8. https://doi.org/10.1021/ bp010106d.

106. Laemmli UK. Cleavage of structural proteins during the assembly of the head of bacteriophage T4. Nature. 1970;227(5259):680-5.

107. Kelly SM, Price NC. The use of circular dichroism in the investigation of protein structure and function. Curr Protein Pept Sci. 2000;1 (4):349-84.

108. Gamboa-Suasnavart RA, Valdez-Cruz NA, Cordova-Davalos L, MartínezSotelo J, Servín-Gonzalez L, Espitia C, Trujillo-Roldán M. The O-mannosylation and production of recombinant APA (45/47 kDa) protein from Mycobacterium tuberculosis in Streptomyces lividans is affected by culture conditions in shake flaks. Microb Cell Fact. 2011;10:110. https:// doi.org/10.1186/1475-2859-10-110.

Ready to submit your research? Choose BMC and benefit from:

- fast, convenient online submission

- thorough peer review by experienced researchers in your field

- rapid publication on acceptance

- support for research data, including large and complex data types

- gold Open Access which fosters wider collaboration and increased citations

- maximum visibility for your research: over $100 \mathrm{M}$ website views per year

At BMC, research is always in progress.

Learn more biomedcentral.com/submissions 